\title{
Cisplatin Cytotoxicity of Auditory Cells Requires Secretions of Proinflammatory Cytokines via Activation of ERK and NF- $\mathrm{kB}$
}

\author{
Hongseob So, ${ }_{1,2}^{1,2}$ Hyunguin Kim, ${ }^{1,4}$ Jeong-Han Lee, ${ }^{1,2}$ Channy Park, ${ }^{1,2}$ Yunha Kim, ${ }^{1,2}$ \\ Eunsook Kim, ${ }^{1,2}$ Jin-Kyung Kim, ${ }^{1,2}$ Ki-Jung Yun, ${ }^{3}$ Kang-Min Lee, ${ }^{4}$ HaA-Yung Lee, ${ }^{5}$ \\ Sung-Kyun Moon, ${ }^{5}$ David J. Lim, ${ }^{5}$ and Raekil Park ${ }^{1,2}$ \\ ${ }^{1}$ Vestibulocochlear Research Center, Wonkwang University School of Medicine, Jeonbuk, 570-749, South Korea \\ ${ }^{2}$ Department of Microbiology, Wonkwang University School of Medicine, 344-7 Shinyong-dong Iksan, Jeonbuk, 570-749, \\ South Korea \\ ${ }^{3}$ Department of Pathology, Wonkwang University School of Medicine, Jeonbuk, South Korea 570-749 \\ ${ }^{4}$ Division of Biological Sciences, Chonbuk National University, Jeonbuk, 561-756, South Korea \\ ${ }^{5}$ Gonda Department of Cell and Molecular Biology, House Ear Institute, Los Angeles, CA 90057, USA
}

Received: 27 December 2006; Accepted: 23 April 2007; Online publication: 22 May 2007

\begin{abstract}
The ototoxicity of cisplatin, a widely used chemotherapeutic agent, involves a number of mechanisms, including perturbation of redox status, increase in lipid peroxidation, and formation of DNA adducts. In this study, we demonstrate that cisplatin increased the early immediate release and de novo synthesis of proinflammatory cytokines, including TNF- $\alpha$, IL-1 $\beta$, and IL-6, through the activation of ERK and NF- $\kappa$ B in HEI-OC1 cells, which are conditionally immortalized cochlear cells that express hair cell markers. Both neutralization of proinflammatory cytokines and pharmacologic inhibition of ERK significantly attenuated the death of HEI-OC1 auditory cells caused by cisplatin and proinflammatory cytokines. We also observed a significant increase in the protein and mRNA levels of proinflammatory cytokines in both serum and cochleae of cisplatin-injected rats, which was suppressed by intraperitoneal injection of etanercept, an inhibitor of TNF- $\alpha$. Immunohistochemical studies revealed that TNF- $\alpha$ expression was mainly located in the spiral ligament, spiral limbus, and the organ of Corti in the cochleae of cisplatin-injected
\end{abstract}

Correspondence to: Raekil Park - Department of Microbiology · Vestibulocochlear Research Center - Wonkwang University School of Medicine, 344-7 Shinyong-dong Iksan · Jeonbuk, 570-749, South Korea. Telephone:+82-63-8506777; fax:+82-63-8520220; email: rkpark@wku.ac.kr rats. NF- $\mathrm{B}$ protein expression, which overlapped with terminal deoxynucleotidyl transferase-mediated dUTP nick-end-labeling-positive signal, was very strong in specific regions of the cochleae, including the organ of Corti, spiral ligament, and stria vascularis. These results indicate that proinflammatory cytokines, especially $\mathrm{TNF}-\alpha$, play a central role in the pathophysiology of sensory hair cell damage caused by cisplatin.

Keywords: apoptosis, inflammation, TNF- $\alpha$, ototoxic mechanisms

\section{INTRODUCTION}

Cisplatin (cis-diamminedichloroplatinum II [CDDP]) is an extensively used chemotherapeutic agent in the treatment of a broad spectrum of tumors (Fram 1992). However, progressive, irreversible side effects of cisplatin, including nephrotoxicity and ototoxicity, greatly impair patient's quality of life and frequently result in a reduction in application dose or discontinuation of treatment.

A number of studies have demonstrated the direct cytotoxic mechanisms of cisplatin including DNA damage (Leibbrandt et al. 1995; Ries et al. 1986), mitochondrial dysfunction (Sugiyama et al. 1989), formation of reactive oxygen species (ROS) (Matsushima et al. 
1998), and caspase activation (Kaushal et al. 2001). In particular, cisplatin ototoxicity occurs primarily in the cochleae, especially in the outer hair cells (OHCs) of the organ of Corti. In recent years, evidence has accumulated to demonstrate that cisplatin ototoxicity is closely related to the increased production of ROS (Rybak et al. 1999). In addition, the inner ear has the capacity to generate an active immune response (Harris 1984; Satoh et al. 2003). Furthermore, hearing loss in some individuals is caused by aggravated immune responses in the inner ear (McCabe 2004). Treatment with immunosuppressive drugs, including steroids, also restores cochlear function in some patients (Kanzaki and Ouchi 1981). Interestingly, Ramesh and Reeves (2002) demonstrated the role of cytokines in the pathogenesis of cisplatin nephrotoxicity. Cisplatin injection led to severe renal failure accompanied by the upregulation of cytokines and chemokines, including TNF- $\alpha$, TGF- $\beta$, RANTES, MIP-2, MCP-1, IL-1 $\beta$, and ICAM-1, in the kidney. In addition, Ramesh and Reeves (2004) also demonstrated that salicylate reduces cisplatin nephrotoxicity by inhibition of TNF- $\alpha$. These results indicate that cisplatin nephrotoxicity is, in part, caused by proinflammatory cytokines and chemokines. In addition, Yoshida et al. (1999) reported that proinflammatory cytokines stimulated spiral ligament fibrocytes to produce inflammatory response mediators, including IL-6, TNF- $\alpha$, MCP-1, KC, MIP-2, sICAM-1, and VEGF. Eventually, the inflammatory mediators induce the infiltration of inflammatory cells, which may prolong the inflammatory response leading to fibrocyte damage and cochlear malfunction. However, there has been no report regarding the cisplatinmediated hearing loss that involves inflammation and apoptosis. In addition, the role of inflammatory response mediators in cisplatin ototoxicity has not yet been elucidated.

ERK, p38, and JNK belong to the mitogenactivated protein kinase (MAPK) family and are important components of signal transduction pathways involved in proinflammatory cytokine production (Guha et al. 2001; Shen et al. 2005) and apoptosis (Wada and Penninger 2004). All three MAPK signaling pathways have also been implicated in NF- $\mathrm{KB}$ activation through the phosphorylation of its inhibitor, I $\kappa \mathrm{B} \alpha$ (Ghosh et al. 1998; Widmann et al. 1999). Cisplatin induces the apoptotic death of various cell types, including immortalized mouse proximal tubule cells (Arany et al. 2004) and ovarian carcinoma cells (Mansouri et al. 2003) through the activation of MAPK signaling pathways.

In the present study, we examined the role of cytokines, including TNF- $\alpha$, IL-1 $1 \beta$, and IL- 6 , in the pathogenesis of cisplatin ototoxicity in vitro and in vivo. In addition, we investigated signaling mechanisms, specifically those involving MAPK and NF- $\mathrm{KB}$, in the cisplatin- induced generation of proinflammatory cytokines in vitro and in vivo. Our results indicate that cisplatin markedly induces proinflammatory cytokine release and production from auditory cells. Among proinflammatory cytokines, TNF- $\alpha$ functions as a major effector in the pathogenesis of inner ear sensory hair cell damage.

\section{METHODS}

\section{Reagents}

Cisplatin, $N$-acetyl cysteine (NAC), reduced glutathione (GSH), and 3-(4,5-dimethylthiazol-2-yl)-2,5-diphenyltetrazolium bromide (MTT) were purchased from Sigma Chemical Co. (Sigma, St. Louis, MO, USA). The plastic culture wares were bought from Becton Dickinson and Company (Franklin Lakes, NJ, USA). Dulbecco's modified essential medium (DMEM), fetal bovine serum (FBS, Gibco BRL, Gaithersburg, MD, USA), and other tissue culture reagents were obtained from Life Technologies Inc. (Gaithersburg, MD, USA). Recombinant mouse TNF- $\alpha$, IL-1 $\beta$, IL-6, anti-TNF- $\alpha$, anti-IL-1 $\beta$, anti-IL-6, and enzyme-linked immunosorbent assay (ELISA) kits (Quantikine ${ }^{\circledR}$ ) for cytokines were purchased from R\&D Systems Inc. (Minneapolis, MN, USA). Anti-NF-kB (p65) and antiIкB antibodies were obtained from Santa Cruz Biotech Inc. (Santa Cruz, CA, USA). Antibodies against MAPKs were bought from Cell Signaling Inc. (Beverly, MA, USA). Pharmacological inhibitors of MAPK, including PD98059, SP600125, SB203580, and U0126, were purchased from Calbiochem (San Diego, CA, USA).

\section{Cell culture and viability}

The establishment and characterization of the conditionally immortalized HEI-OC1 auditory cells was described in Kalinec et al. (2003). Expression of the OHC specific markers, including Prestin and Myosin 7a, suggests that HEI-OC1 cells represent OHC precursors. HEI-OC1 cells were maintained in high glucose DMEM containing 10\% FBS. For the experiments described below, cells were cultured under permissive conditions: $33^{\circ} \mathrm{C}, 7 \% \mathrm{CO}_{2}$ in DMEM supplemented with $10 \%$ FBS. Cells $\left(3 \times 10^{4}\right.$ cells/well of a 24-well plate) were plated for $16 \mathrm{~h}$ and further incubated with $20 \mu \mathrm{M}$ cisplatin for various time periods. To determine the cell viability, MTT $(0.25 \mathrm{mg})$ was added to $1 \mathrm{ml}$ of cell suspension for $4 \mathrm{~h}$. After three washes of cells with phosphate-buffered saline (PBS, $\mathrm{pH}$ 7.4), the insoluble formazan product was dissolved in DMSO. Then, the optical density (OD) of each culture well was measured using Microplate reader (Titertek Multiskan, Flow Laboratories) at $590 \mathrm{~nm}$. The OD in control cells was taken as $100 \%$ of viability. To examine 
the effects of TNF- $\alpha$, IL- $1 \beta$, and IL- 6 on cell viability, cells were exogenously treated with various concentrations of cytokines for $40 \mathrm{~h}$. In addition, to neutralize the effects of proinflammatory cytokines, antibodies against TNF- $\alpha$ $(1 \mathrm{ng} / \mathrm{ml})$, IL-1 $\beta(1 \mathrm{ng} / \mathrm{ml})$, and IL-6 $(1 \mathrm{ng} / \mathrm{ml})$ were added to cultures for $30 \mathrm{~min}$ and then further maintained with $20 \mu \mathrm{M}$ cisplatin for $36 \mathrm{~h}$. In experiments involving block of new protein synthesis, HEI-OC1 cells were incubated in medium containing $20 \mu \mathrm{g} / \mathrm{ml}$ cycloheximide for $30 \mathrm{~min}$ followed by cisplatin exposure.

\section{Measurement of proinflammatory cytokines by ELISA}

To measure the secretion of proinflammatory cytokines from cisplatin-treated HEI-OC1 cells, culture supernatants were harvested at each time point and the levels of secreted proinflammatory cytokines were determined by ELISA (Quantikine Cytokine Kits, R\&D Systems Inc.) according to the manufacturer's instructions.

\section{Flow cytometry analysis}

To examine the presence and release of preformed proinflammatory cytokines by cisplatin from HEIOC1 cells, flow cytometry analysis was performed. Cells $\left(5 \times 10^{5}\right)$ were washed in PBS containing $1 \%$ bovine serum albumin (BSA), and then fixed in $4 \%$ paraformaldehyde. Cells were treated with permeabilization buffer $(0.1 \%$ saponin in PBS containing $0.1 \%$ sodium azide and $1 \%$ fetal calf serum) for $15 \mathrm{~min}$, and then stained with monoclonal antibodies specific for TNF- $\alpha$, IL-1 $1 \beta$, and IL6 for $30 \mathrm{~min}$. Cells were subsequently stained with fluorescein isothiocyanate-conjugated anti-mouse IgG antibody for $30 \mathrm{~min}$. After washes, stained cells were fixed in $1 \%$ paraformaldehyde at $4^{\circ} \mathrm{C}$ until analyzed. Negative control was prepared by incubating with an isotype-matched control mouse immunoglobulin, and then stained with the same method. Flow cytometric analyses $(10,000$ events per sample) were performed in a FACSCalibur system (Becton Dickinson GmbH, San Jose, CA, USA) and evaluated with the CellQuest software.

\section{Preparation of cytosolic and nuclear extracts}

Cells were washed with ice-cold PBS, scraped, and centrifuged at $1,000 \times g$ for $5 \mathrm{~min}$ at $4^{\circ} \mathrm{C}$. The cell pellet was resuspended in $200 \mu \mathrm{l}$ of lysis buffer $(10 \mathrm{mM}$ HEPES, pH 7.9, $1.5 \mathrm{mM} \mathrm{MgCl}, 10 \mathrm{mM} \mathrm{KCl}, 0.5 \mathrm{mM}$ phenylmethylsulfonyl fluoride, and $0.5 \mathrm{mM}$ dithiothreitol) and incubated on ice for $15 \mathrm{~min}$. At the end of this incubation, $10 \mu \mathrm{l}$ of $10 \% \mathrm{NP}-40$ was added and the tube was vortexed for $10 \mathrm{~s}$. After centrifugation at $13,000 \times g$ for $1 \mathrm{~min}$ at $4^{\circ} \mathrm{C}$, supernatant (cytosolic extract) was collected and stored at $-80^{\circ} \mathrm{C}$, whereas the pellet was further processed to obtain nuclear extracts. The pellet was resuspended in extraction buffer ( $5 \mathrm{mM}$ HEPES, pH 7.9, $1.5 \mathrm{mM} \mathrm{MgCl}, 0.5 \mathrm{mM}$ phenylmethylsulfonyl fluoride, $0.2 \mathrm{mM}$ EDTA, $0.5 \mathrm{mM}$ dithiothreitol, and glycerol $25 \% \mathrm{vol} / \mathrm{vol}$ ) and incubated for $30 \mathrm{~min}$ at $4^{\circ} \mathrm{C}$. Nuclear extract was isolated by centrifugation at $13,000 \times \mathrm{g}$ for $30 \mathrm{~min}$ at $4^{\circ} \mathrm{C}$. The supernatant was aliquoted and stored at $-80^{\circ} \mathrm{C}$ until used for Western blot analysis. Protein concentration was determined by the Lowry method.

\section{Western blot analysis}

Western blot analysis was performed as follows. Briefly, cells were harvested and washed twice with ice-cold PBS. Whole and nuclear/cytosolic-fractionated lysates were subjected to electrophoresis on $12 \%$ sodium dodecyl sulfate (SDS)-polyacrylamide gels for $3 \mathrm{~h}$ at $20 \mathrm{~mA}$ and then transferred onto nitrocellulose. The membrane was incubated in 5\% (wt/vol) dried milk protein in PBS containing $0.05 \%$ (vol/vol) Tween-20 (PBS-T) for $1 \mathrm{~h}$, washed in PBS-T, and then further reacted with primary antibody $(1: 1,000)$ for $1 \mathrm{~h}$. The membrane was extensively washed with PBS-T and then incubated with anti-rabbit IgG antibody conjugated to HRP $(1: 3,000)$ for $1 \mathrm{~h}$. After extensive washes, protein bands on the membrane were visualized using chemiluminescent reagents according to the manufacturer's instructions (Supersignal Substrate, Pierce, Rockford, IL, USA).

\section{Luciferase reporter assay}

Cells were suspended in DMEM containing 10\% FBS, seeded on 24-well culture plates at $2 \times 10^{4}$ cells/well, and adapted for $12 \mathrm{~h}$. Cells were incubated for $1 \mathrm{~h}$ with a total of $170 \mathrm{ng}$ of plasmids (85 ng of NF-kB-dependent luciferase reporter and $85 \mathrm{ng}$ of pcDNA3- $\beta$-gal) (So et al. 2003), $1 \mu \mathrm{l}$ of Tfx ${ }^{\mathrm{TM}}-50$ reagent (Promega, Madison, WI, USA), and $200 \mu \mathrm{l}$ of serum-free DMEM. In all, $800 \mu \mathrm{l}$ of DMEM containing FBS was then added and incubation continued. After $24 \mathrm{~h}$ of incubation, cells were treated with cisplatin $(20 \mu \mathrm{M})$ for the indicated periods. Cells were washed twice with PBS buffer and then lysed in reporter lysis buffer. Luciferase activity was measured with a luciferase assay system (Promega) according to the manufacturer's instructions. Luciferase activity was measured in triplicate, averaged, and then normalized with $\beta$-galactosidase activity using the galactosidase assay system (Galacto-Light, Tropix Inc., MA, USA) according to the manufacturer's instructions.

\section{Determination of ROS production}

The intracellular ROS level was measured using a fluorescent dye, 2',7'-dichlorofluorescein diacetate (DCFH-DA, Molecular Probes, Eugene, OR, USA). In 
the presence of an oxidant, DCFH is converted into the highly fluorescent $2^{\prime}, 7^{\prime}$-dichlorofluorescein. Cells were plated in 96-well culture plates. After defined preincubation periods, cells were rinsed with PBS. To each well, serum-free DMEM containing $10 \mu \mathrm{M}$ DCFH-DA was added, incubated at $37^{\circ} \mathrm{C}$ for $1 \mathrm{~h}$, and then rinsed once and treatment was started. ROS production was measured at $24 \mathrm{~h}$ after treatment using a microplate reader equipped with a spectrofluorometer at an emission wavelength of $538 \mathrm{~nm}$ and extinction wavelength of $485 \mathrm{~nm}$. Relative ROS production was expressed as the change in fluorescence of experimental groups compared to that of the appropriate controls $(100 \%)$.

\section{In vivo experiment of cisplatin ototoxicity}

Twelve adult female Sprague-Dawley rats in each group, weighing between 160 and $190 \mathrm{~g}$ at 8 weeks, were used in this study. The animals were fed a standard commercial diet, housed in a room at 20$22^{\circ} \mathrm{C}$ ambient temperature with a relative humidity of $50 \pm 5 \%$ and 12:12 $\mathrm{h}$ of light and dark cycle. The animals were randomly divided into three groups (group 1, control; group 2, cisplatin-treated; group 3, cisplatin plus etanercept-treated). Group 1 animals received intraperitoneal injection of PBS. Group 2 animals were intraperitoneally administered with cisplatin only ( $4 \mathrm{mg} / \mathrm{kg}$, body weight) for 4 days. To neutralize TNF- $\alpha$ pharmacologically, group 3 animals were intraperitoneally given etanercept $(400 \mu \mathrm{g} / \mathrm{kg}$, body weight) at $12 \mathrm{~h}$ before injection of cisplatin for four consecutive days. The animals in all groups were killed under anesthesia on the next day after final cisplatin injection, and the whole temporal bone of right ear was removed. Before killing, blood was collected into commercial tubes containing EDTA. The serum was stored at $-30^{\circ} \mathrm{C}$ until analysis for cytokine measurements. The experimental protocol was approved by the Animal Care and Use Committee at the Wonkwang University School of Medicine.

\section{Immunohistochemical studies and TUNEL assay}

The removed temporal bone was fixed in $4 \%$ paraformaldehyde for $16 \mathrm{~h}$, decalcificated with $10 \%$ EDTA in PBS for 2 weeks, dehydrated, and embedded in paraffin wax. Sections of $5 \mu \mathrm{m}$ were deparaffinized in xylene and rehydrated through graded concentrations of ethanol. For immunohistochemical study, the LSAB-kit Universal K680 (DAKO, Carpinteria, CA, USA) was used and all the procedures were carried out according to the manufacturer's instruction. The endogenous peroxidase was blocked with $3 \%$ hydrogen peroxide for $5 \mathrm{~min}$ at room temperature. After sections were washed in PBS and nonspecific binding was blocked with $1 \%$ BSA for $1 \mathrm{~h}$. Then, primary antibody
(1:200 diluted) was added to the slides, and incubation proceeded for $1 \mathrm{~h}$. After repeated washes with PBS, the section was incubated with biotinylated secondary antibody for $1 \mathrm{~h}$ and then covered for $15 \mathrm{~min}$ with streptavidin peroxidase. Finally, after repeated washes with PBS, the section was stained in a freshly prepared substrate solution (3 mg of 3-amino-9-ethylcarbazole

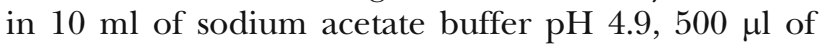
dimethylformamide, $0.03 \%$ hydrogen peroxide) for $10 \mathrm{~min}$. The nuclei of immunostained cells were counterstained with Mayer's hematoxylin (SigmaAldrich Co.). The following primary antibodies were employed: anti-TNF- $\alpha$ (goat polyclonal anti-mouse TNF- $\alpha$, R.\&D Systems), anti-IL-1 $\beta$ (goat polyclonal anti-mouse IL-1 $\beta$, R.\&D Systems), anti-IL-6 (goat polyclonal anti-mouse IL-6, R.\& D Systems), and antiNF-кB p65 (rabbit polyclonal IgG, Santa Cruz).

Apoptotic cells were detected in situ utilizing the terminal deoxynucleotidyl transferase-mediated dUTP nick-end-labeling (TUNEL) assay (TUNEL POD kit, Roche Molec Biochemic, Mannheim, Germany). Briefly, a section was deparaffinized and rehydrated. After incubation with $20 \mu \mathrm{g} / \mathrm{ml}$ proteinase $\mathrm{K}$ (Boehringer Mannheim, Mannheim, Germany), the blocking of endogenous peroxidase was carried out using $2 \% \mathrm{H}_{2} \mathrm{O}_{2}$ in methanol for $30 \mathrm{~min}$ at reverse transcriptase (RT). Then tissue section was washed in PBS and incubated with labeling solution for $1 \mathrm{~h}$ at $37^{\circ} \mathrm{C}$. After washing, the section was incubated with converter POD for $30 \mathrm{~min}$. 3,3'-Diaminobenzidine was used as a substrate. The nuclei of immunostained cells were counterstained with Mayer's hematoxylin (Sigma-Aldrich Co.).

\section{RT-PCR amplification}

Total RNA was extracted from whole cochleae of left ear of rat with the use of TRIzol (Invitrogen) according to the manufacturer's protocol. Singlestranded cDNA was synthesized from total RNA. Then, PCR with Taq DNA polymerase (Takara, Takara Shuzo, Japan) was performed for 30 cycles using the following protocol: $95^{\circ} \mathrm{C}$ for $40 \mathrm{~s}, 58^{\circ} \mathrm{C}$ for $40 \mathrm{~s}$, and $72^{\circ} \mathrm{C}$ for $50 \mathrm{~s}$. Then, $10 \mu \mathrm{l}$ of the PCR products was separated on $1.2 \%$ agarose gel and visualized under UV. The sequences of primers used for PCR amplification were as follows: $\beta$-actin (forward 5'-GAA GAG CTA TGA GCT GCC TGA-3' and reverse 5'-TGA TCC ACA TCT GCT GGA AGG-3'), TNF- $\alpha$ (forward 5'-CAG GGG CCA CCA CGC TCT TC- 3 ' and reverse 5'-CTT GGG GCA GGG GCT CTT GAC-3'), IL-1 $\beta$ (forward 5'-AAG GAG ACC AAG CAA CGA C-3' and reverse 5'-GAG ATT GAG CTG TCT GCT CA-3'), and IL-6 (forward 5'-TTG CCT TCT TGG GAC TGA TGC-3' and reverse 5'-TTG GAA ATT GGG GTA GGA AGG A-3'). 
Statistical analysis

Each experiment was performed at least three times, and all values are represented as means \pm SD of three or six observations. One-way ANOVA or post hoc test for different interactions within one test was used to analyze a statistical significance of the results. Values of $p<0.05$ were considered statistically significant.

\section{RESULTS}

We initially investigated whether HEI-OC1 cells could produce the proinflammatory cytokines in response to cisplatin application. Culture supernatants of HEIOC1 cells were harvested at $0.25,0.5,1,3,6,12,18$, and $24 \mathrm{~h}$ after exposure to $20 \mu \mathrm{M}$ cisplatin. The secretion of each proinflammatory cytokine, includ-

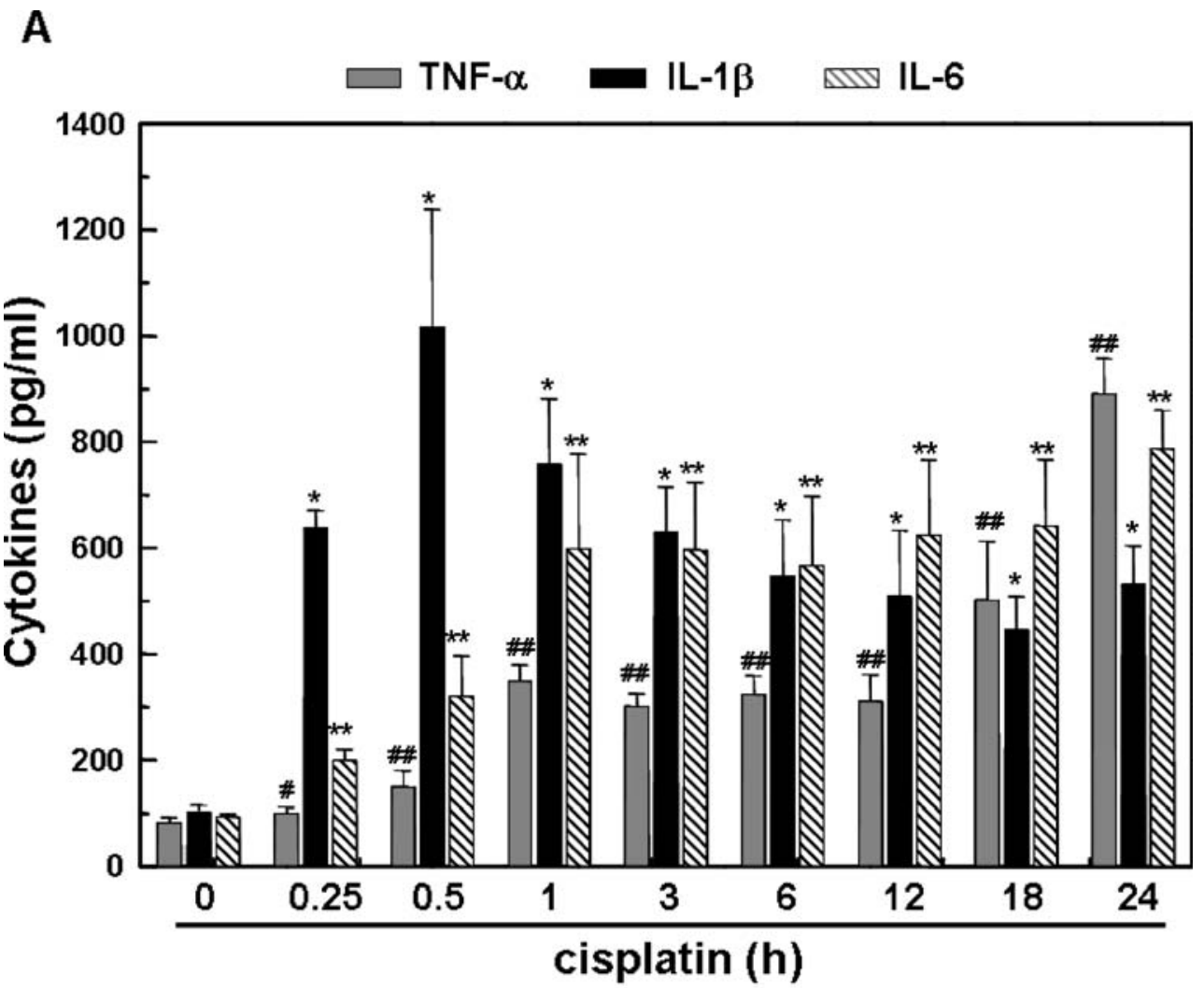

B

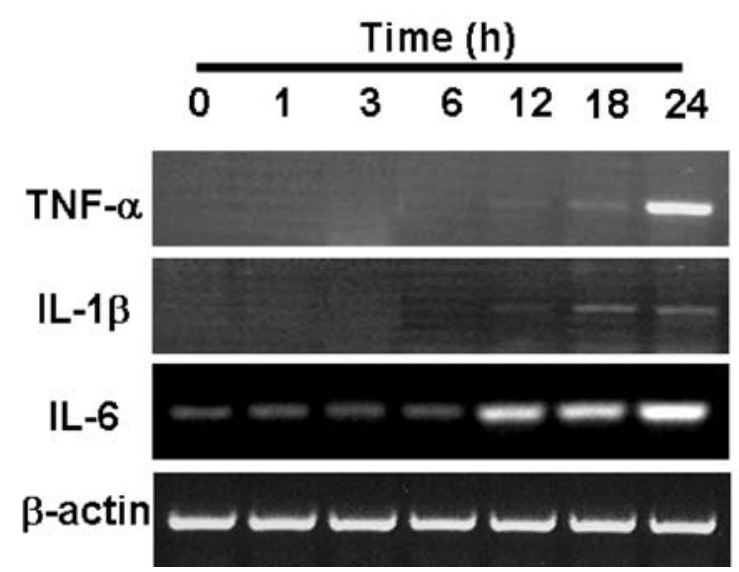

FIG. 1. Time-dependent increase of proinflammatory cytokine secretion and mRNA transcription in cisplatin-treated HEI-OC1 auditory cells. A Cells were treated with $20 \mu \mathrm{M}$ cisplatin for $24 \mathrm{~h}$. Proinflammatory cytokines from culture supernatant were measured by ELISA. The data represent the mean \pm SD of six culture supernatants. $\# p<0.05, \# \# p<0.01$ (TNF- $\alpha$ ), ${ }^{*} p<0.01$ (IL-1 $\beta$ ), and $* * p<0.01$ (IL-6) by one-way ANOVA, compared with each media control group. B Cells were treated with cisplatin for the indicated periods. Total RNA was then isolated by TRIzol and CDNA was synthesized by reverse transcription. TNF- $\alpha$, IL-1 $\beta$, IL-6, and $\beta$-actin cDNAs were amplified using specific primer sets. 
ing TNF- $\alpha$, IL-1 $\beta$, and IL-6, was determined by ELISA. As shown in Fig. 1A, cisplatin treatment resulted in a marked increase of TNF- $\alpha$ secretion, which was observed as early as $0.5 \mathrm{~h}$ and reached a primary peak level of $348 \pm 31 \mathrm{pg} / \mathrm{ml}(n=6)$ at $1 \mathrm{~h}$. However, TNF- $\alpha$ secretion showed a secondary increase beginning at $18 \mathrm{~h}$ after cisplatin treatment, reaching a maximum level of $890 \pm 67 \mathrm{pg} / \mathrm{ml}(n=6)$ at $24 \mathrm{~h}$, and gradually decreasing in a time-dependent manner thereafter. Cisplatin also induced an increased release of IL-1 $\beta$, which was already sixfold higher at $0.25 \mathrm{~h}$ compared to the control level of resting cells and reached a peak level of $1,014 \pm 244 \mathrm{pg} / \mathrm{ml}(n=6)$ at $0.5 \mathrm{~h}$. IL-6 secretion gradually increased up to $1 \mathrm{~h}$, sustained this level up to $12 \mathrm{~h}$, and then increased again to $786 \pm 73 \mathrm{pg} / \mathrm{ml}(n=6)$ at $24 \mathrm{~h}$.

Next we examined the transcriptional activation of proinflammatory cytokines in cisplatin-treated HEIOC1 cells (Fig. 1B). An increase in the RT-PCR products of proinflammatory cytokine mRNAs was apparent after $12 \mathrm{~h}$ of cisplatin treatment, although a low level of IL-6 mRNA was consistently expressed in resting HEI-OC1 cells. De novo mRNA synthesis did not coincide with secretion of the cytokines as shown by the 12-h delay in cisplatin-treated cells. These data clearly indicate that the rapid secretion of proinflammatory cytokines at early time points is not directly caused by transcriptional activation of proinflammatory cytokine genes. Therefore, we investigated the possibility that HEI-OC1 cells contain preexisting stores of proinflammatory cytokines, which could be released in response to cisplatin at early time points. To address this question, cells were pretreated with cycloheximide to block the de novo synthesis of proinflammatory cytokine proteins in cisplatin-treated cells (Fig. 2). Pretreatment with cycloheximide did not significantly affect the early secretion of proinflammatory cytokines TNF- $\alpha$, IL- $1 \beta$, and IL-6 in cells treated with cisplatin up to $12 \mathrm{~h}$ (data not fully shown). However, pretreatment with cycloheximide did result in a significant decrease in the secretion of TNF- $\alpha$ and IL- 6 after $18 \mathrm{~h}$ of cisplatin
A

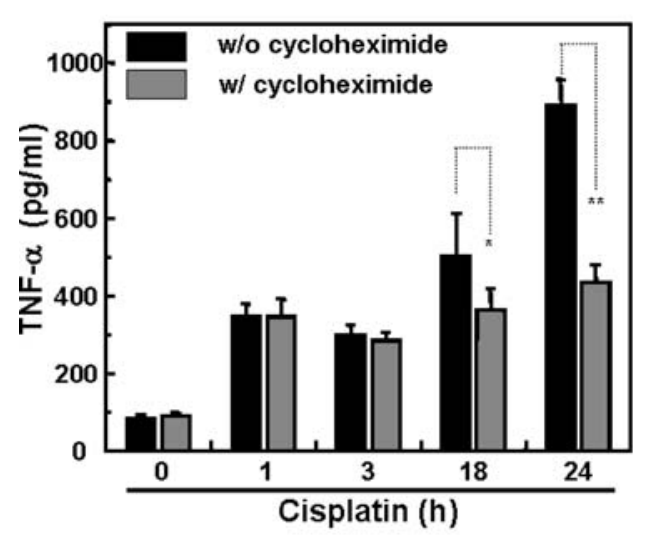

B

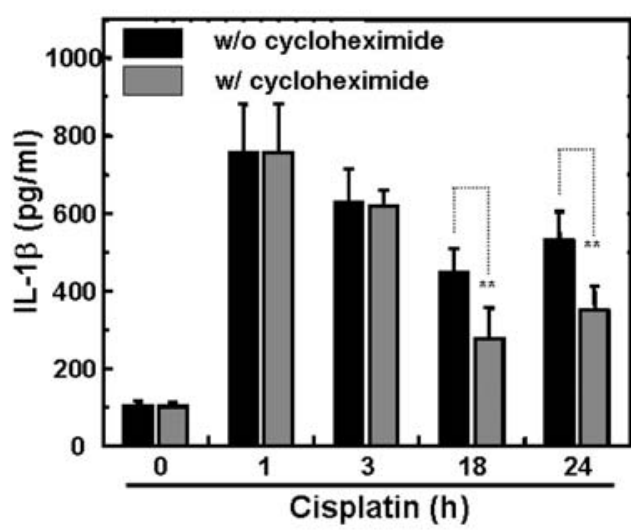

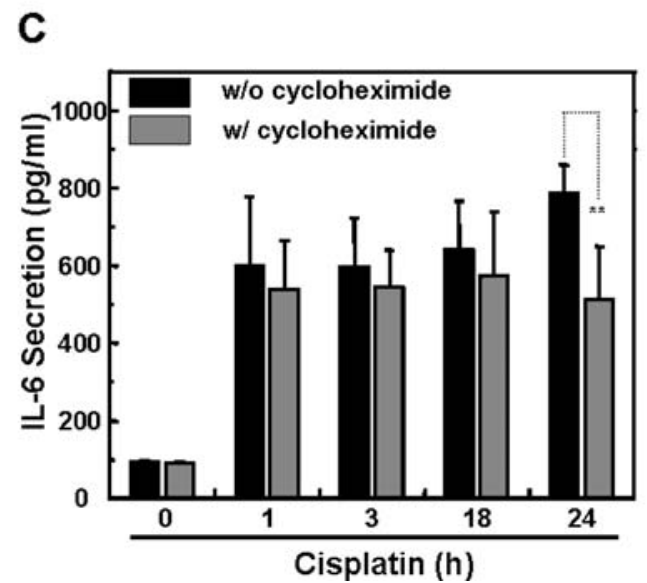

FIG. 2. Effect of cycloheximide on the cisplatin-induced secretion of proinflammatory cytokines in HEI-OC1 auditory cells. Cells were treated with $20 \mu \mathrm{M}$ cisplatin in the absence or presence of cycloheximide for up to $24 \mathrm{~h}$. Proinflammatory cytokines from culture supernatants were measured by ELISA. The data represent the mean \pm SD of six culture supernatants. ${ }^{*} p<0.05$ and ${ }^{* *} p<0.01$ by one-way ANOVA. A Release of TNF- $\alpha$, B release of IL- $1 \alpha$, and C release of IL- 6 . 
A

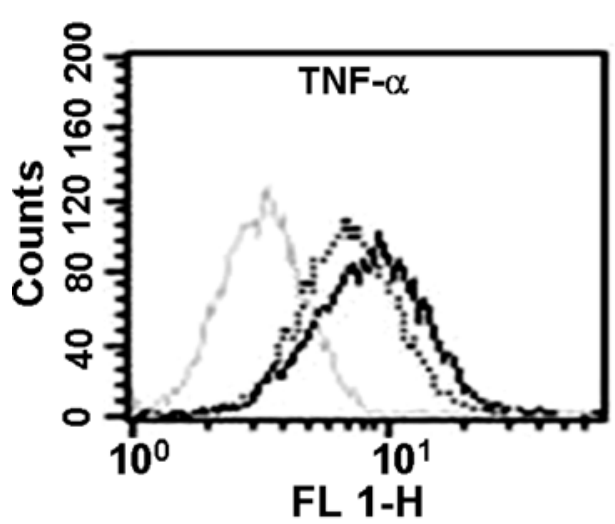

C

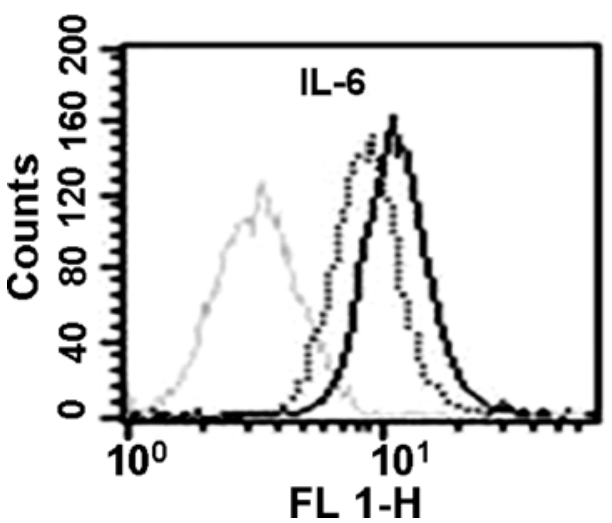

B

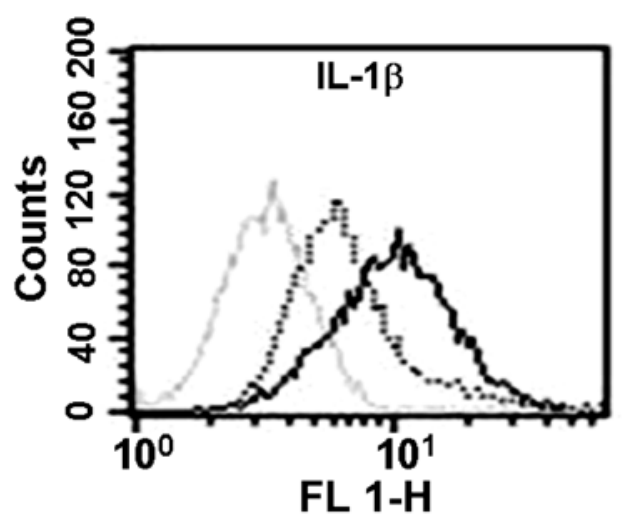

FIG. 3. Early immediate release of preexisting inflammatory cytokine stores from HEI-OC1 auditory cells treated with cisplatin. After exposure to $20 \mu \mathrm{M}$ cisplatin for $1 \mathrm{~h}$, cells were stained with monoclonal antibodies specific for TNF- $\alpha$ (A), IL-1 $\beta$ (B), and IL-6 (C) for 30 min, and analyzed by flow cytometer (FACSCalibur system). Gray line $=$ Control cells stained with isotype matched normal IgG, dotted line $=$ cisplatin-exposed cells stained with specific antibodies against each cytokine, black line $=$ control cells stained with specific antibodies against each cytokine.

treatment (Fig. 2A,C). These data suggest that de novo protein synthesis may contribute to the secretion of these cytokines at later time points. To further examine the apparent release of preexisting stores of proinflammatory cytokines by fluorescence-activated cell sorter analysis, cells were permeabilized and stained for intracellular cytokines with specific antibodies (Fig. 3). After a 1-h exposure, we observed a leftward shift of fluorescence signals from TNF- $\alpha$, IL- $1 \beta$, and IL-6 in cisplatin-treated cells compared to control cells. These results suggest that HEI-OC1 cells contain preexisting stores of proinflammatory cytokines, which are immediately released upon the addition of cisplatin.

Effect of endogenous and exogenous proinflammatory cytokines on cisplatin cytotoxicity

To determine the role of proinflammatory cytokines on cisplatin cytotoxicity, endogenously secreted proinflammatory cytokines were neutralized by pretreatment of cell cultures with anti-TNF- $\alpha(1 \mathrm{ng} / \mathrm{ml})$, anti-IL1 $\beta$
( $1 \mathrm{ng} / \mathrm{ml})$, and anti-IL-6 $(1 \mathrm{ng} / \mathrm{ml})$ antibodies $30 \mathrm{~min}$ before cisplatin exposure (Fig. 4). TNF- $\alpha$ neutralization with anti-TNF- $\alpha$ antibody significantly increased the viability of HEI-OC1 cells in the presence of cisplatin, however pretreatment with anti-IL-1 $\beta$ or -IL6 antibodies did not exert any notable cytoprotective effects. Interestingly, there was a synergistic protective effect when all three neutralizing antibodies were used in combination before cisplatin treatment (Fig. 4A). When endogenously secreted TNF- $\alpha$, IL-1 $\beta$, and IL-6 were neutralized by applying $10 \mathrm{ng} / \mathrm{ml}$ concentration of each neutralizing antibody, each antibody alone or combined antibodies successfully inhibited cisplatininduced cytotoxicity (data not shown). We also confirmed that the viability of cisplatin-treated cells maintained with an IgG control antibody $(54 \pm 4 \%$, $n=6)$ was not significantly different from cells treated with cisplatin only $(58 \pm 1 \%, n=6)$.

Next, to further confirm the direct roles of proinflammatory cytokines in the cytotoxicity of cisplatin, cells were exogenously treated with TNF- $\alpha$, IL-1 $\beta$, and IL-6, alone or in combination, for $40 \mathrm{~h}$. 


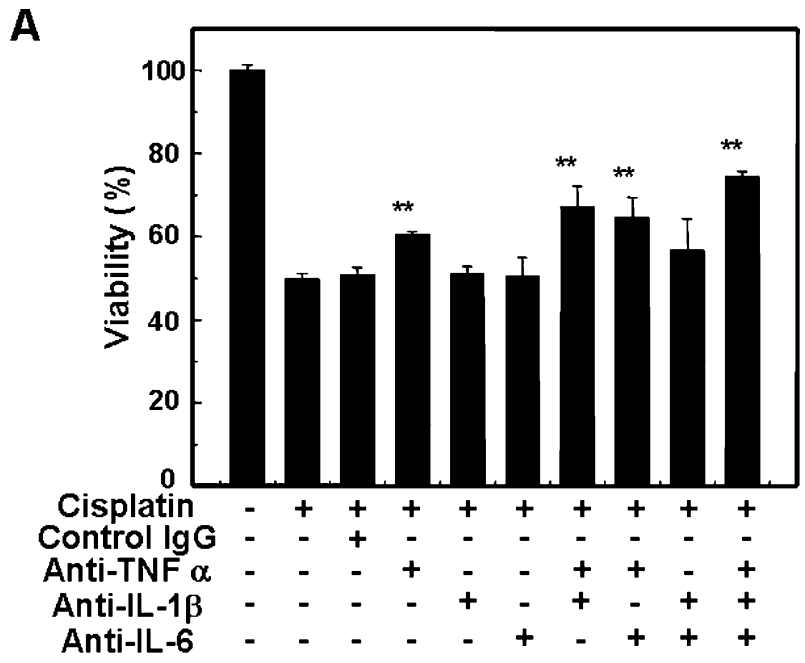

B

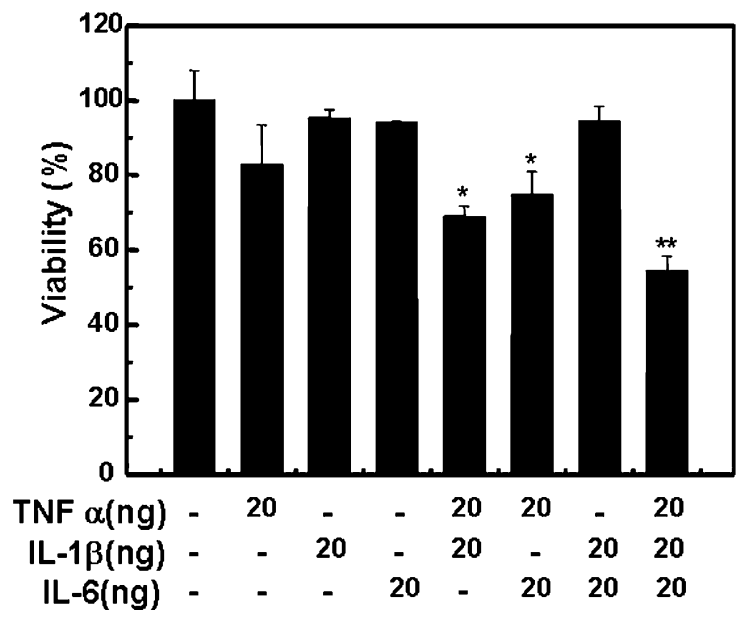

FIG. 4. Effect of proinflammatory cytokines on cisplatin cytotoxicity. A Cells were pretreated with neutralizing antibodies, including anti-TNF- $\alpha(1 \mathrm{ng} / \mathrm{ml})$, anti-IL1 $\beta(1 \mathrm{ng} / \mathrm{ml})$, and anti-IL-6 $(1 \mathrm{ng} / \mathrm{ml})$, for $30 \mathrm{~min}$ and further maintained in $20 \mu \mathrm{M}$ cisplatin for $36 \mathrm{~h}$. Then, cell viability was measured by MTT assay. B Cells were exogenously treated with $20 \mathrm{ng} / \mathrm{ml}$ concentrations of each TNF- $\alpha$, IL-1 $\beta$, and IL- 6 alone or in combination for $48 \mathrm{~h}$. Cell viability was measured by MTT assay. ${ }^{*} p<0.05$ and $* * \quad p<0.01$ by one-way ANOVA, compared with the media-only control group $(n=3)$.

The exogenous treatment with TNF- $\alpha$, IL-1 $\beta$, or IL- 6 alone in concentrations less than $20 \mathrm{ng} / \mathrm{ml}$ did not significantly affect the viability of HEI-OC1 cells (Fig. 4B). However, treatment with $25 \mathrm{ng} / \mathrm{ml}$ doses of each of the three proinflammatory cytokines significantly decreased cell viability (data not shown). Interestingly, treatment with TNF- $\alpha$ combined with other cytokines at $20 \mathrm{ng} / \mathrm{ml}$ concentrations usually exerted a much more potent cytotoxic effect when compared with individual cytokine treatment or IL- $1 \beta$ and IL- 6 in combination. These results indicate that TNF- $\alpha$ plays a key role in the cytotoxicity of cisplatin toward HEI-OC1 cells.
Nuclear translocation of NF- $\kappa \mathrm{B}$ in cisplatin-treated $\mathrm{HEI}-\mathrm{OC} 1$ cells

The transcription factor NF- $\mathrm{KB}$ is involved in regulating the expression of proinflammatory cytokines and other inflammatory mediators that participate in acute inflammatory responses (Abraham 2003). To investigate the nuclear translocation of NF-KB because of cisplatin, cells were treated with cisplatin up to $240 \mathrm{~min}$, and fractionated into the nuclear and cytosolic parts for Western blotting. Nuclear translocation of NF- $\mathrm{KB}$ was observed by $30 \mathrm{~min}$, and further increased after 60-120 min of cisplatin treatment. Consistent with this result, cytoplasmic NF- $\mathrm{BB}$ was seen to decrease between $30-120 \mathrm{~min}$ after the addition of cisplatin. Cytoplasmic IкB- $\alpha$ expression was also decreased at $60 \mathrm{~min}$ following exposure to cisplatin (Fig. 5A). Consistent with the nuclear translocation level of NF- $\mathrm{KB}$ by cisplatin, the enzymatic activity of NF-кB-dependent luciferase reporter gene was significantly increased after $30 \mathrm{~min}$ of cisplatin exposure (Fig. 5B).

We next examined whether the secretion of proinflammatory cytokines at early time points is directly involved with NF- $\mathrm{\kappa B}$ activation in cisplatintreated cells. Cells were pretreated with anti-TNF- $\alpha$, anti-IL-1 $\beta$, and anti-IL- 6 antibodies alone or in combination for $0.5 \mathrm{~h}$ before cisplatin exposure. The nuclear translocation of NF- $\mathrm{KB}$ was then assessed after $1 \mathrm{~h}$ of cisplatin treatment (Fig. 5C). The neutralization of TNF- $\alpha$ markedly inhibited the nuclear translocation of NF- $\kappa \mathrm{B}$ and caused a decrease of the cytosolic IKB- $\alpha$ expression in cisplatin-treated cells. Furthermore, we found that the direct addition of TNF- $\alpha$, IL-1 $\beta$, or IL- 6 markedly increased the nuclear translocation of NF- $\mathrm{BB}$ in HEI-OC1 auditory cells (Fig. 5D). Also, various combinations of these cytokines synergistically augmented the nuclear translocation of NF-KB. These data indicate that the proinflammatory cytokines released after cisplatin treatment induce the activation of NF- $\mathrm{BB}$ through its nuclear translocation because of the dissociation of NF- $\kappa \mathrm{B} / \mathrm{I} \kappa \mathrm{B}-\alpha$ complexes.

Effect of antioxidants on the secretion of proinflammatory cytokines in cisplatin-treated HEI-OC1 cells

In our previous report, we demonstrated that the increase in intracellular ROS from cisplatin-treated HEI-OC1 cells was directly involved in cytotoxicity, which was prevented by pretreatment with antioxidants such as NAC and GSH (So et al. 2005). Therefore, we examined the link between the secretion of proinflammatory cytokines and ROS generation in cisplatin-treated cells. Proinflammatory 
A
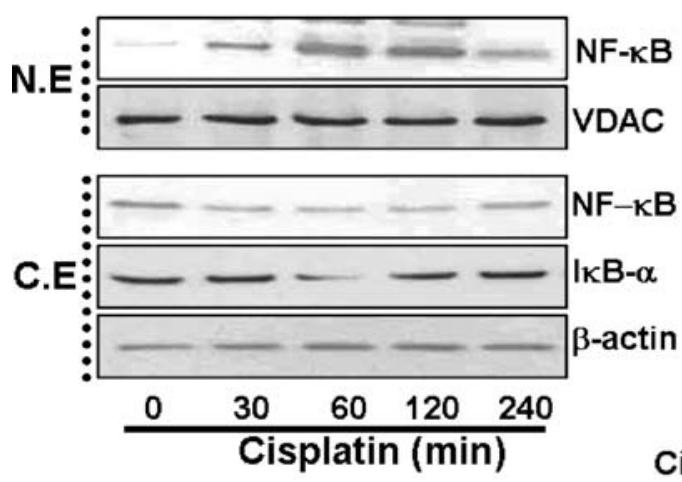

B

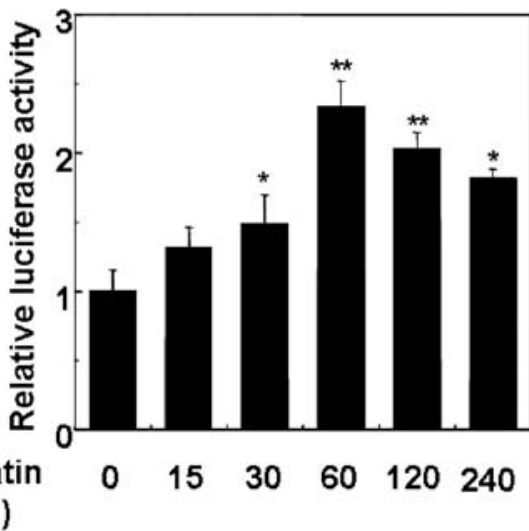

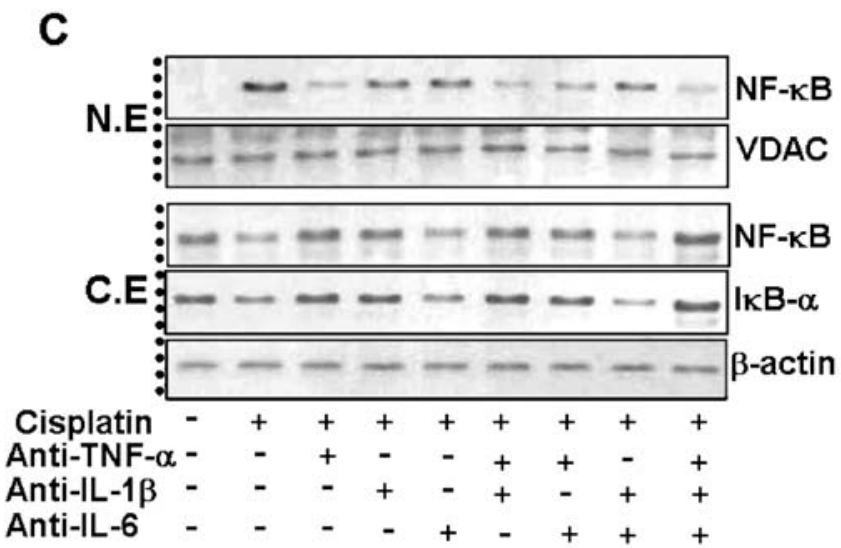

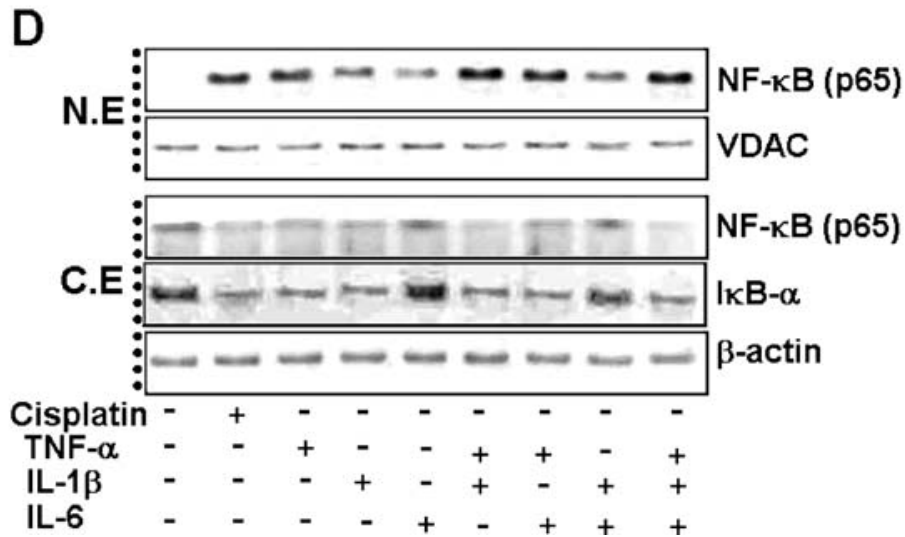

FIG. 5. Nuclear translocation of NF- $\mathrm{B}$ in cisplatin-treated HEI-OC1 auditory cells. A Cytosolic and nuclear fractions from cells treated with $20 \mu \mathrm{M}$ cisplatin for indicated periods were subjected to $12 \%$ SDS polyacrylamide gel electrophoresis and immunoblotted with antibodies specific for NF-

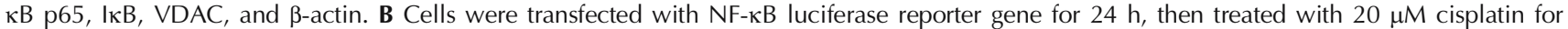
indicated periods. Luciferase activity was measured at indicated time points. ${ }^{*} p<0.05$ and $* * p<0.01$ by one-way ANOVA, compared with media control group $(n=3)$. Cells were treated with cisplatin in the presence of $10 \mathrm{ng} / \mathrm{ml}$ concentrations of single or combined antibodies specific for TNF$\alpha$, IL-1 $\beta$, and IL-6 for $60 \mathrm{~min}(\mathbf{C})$ or $20 \mathrm{ng} / \mathrm{ml}$ concentrations of each cytokine alone or in combination for $60 \mathrm{~min}(\mathbf{D})$. Cytosolic and nuclear

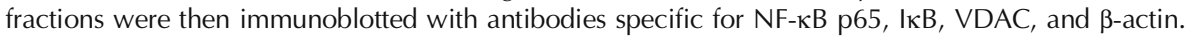

cytokines were measured using ELISA with HEI-OC1 cells treated with cisplatin (Fig. 6). Pretreatment with antioxidants NAC and GSH resulted in a slight decrease of the secretion of TNF- $\alpha$, IL- $1 \beta$, and IL- 6 ; however, this change was not statistically significant. Moreover, our results demonstrated that pretreatment with NAC and GSH significantly protected cells from the cytotoxicity of both cisplatin and a combination of proinflammatory cytokines (Fig. 7A). These results suggest that the secretion of proinflammatory cytokines in response to cisplatin may be an upstream signaling event leading to ROS generation. To address this question, cells were exogenously treated with cytokine mixtures at $20 \mathrm{ng} / \mathrm{ml}$ each of TNF- $\alpha$, 
IL- $1 \beta$, and IL- 6 for $24 \mathrm{~h}$, and then intracellular ROS levels were monitored using a peroxide-sensitive fluorescent probe, DCFH-DA (Fig. 7B). Exogenous treatment with cytokine mixtures and cisplatin significantly increased the generation of intracellular ROS, which was markedly inhibited by pretreatment with NAC and GSH.

Pharmacologic inhibition of MEK1/ERK activity rescued HEI-OC1 cells from cisplatin cytotoxicity

To investigate the signaling pathway by which cisplatin stimulates the secretion of proinflammatory cytokines in HEI-OC1 cells, we examined the involvement of the MAPKs ERK, JNK, and p38. Exposure of cells to $20 \mu \mathrm{M}$ cisplatin induced the phosphorylation of all three MAPKs with a peak at $0.5 \mathrm{~h}$ (Fig. 8A). Phosphorylation of p38 was detected at $0.25 \mathrm{~h}$, reached a peak at $0.5 \mathrm{~h}$, and was sustained for $3 \mathrm{~h}$ after cisplatin treatment. However, the phosphorylation of ERK and JNK was sustained for up to $24 \mathrm{~h}$ after cisplatin exposure (Fig. 8A). Next, to examine the role of MAPKs on the cisplatin cytotoxicity, cells were pretreated with pharmacological inhibitors of p38, JNK, or MEK1 before exposure to cisplatin (Fig. 8B). Pharmacological inhibition of p38 with SB203580 $(10 \mu \mathrm{M})$ did not affect the viability of cisplatin-treated cells. Pretreatment with JNK inhibitor SP600125 (10 $\mu \mathrm{M})$ showed a slight but statistically significant attenuation of cytotoxicity. However, pretreatment of MEK1/ERK inhibitors, including PD98059 and U0126, markedly decreased the cytotoxicity of cisplatin as measured by MTT assay.

To determine the role of MAPKs on proinflammatory cytokine release in cisplatin-treated HEI-OC1 cells, cells were treated with cisplatin in the presence of MAPK inhibitors. The secretion of TNF- $\alpha$, IL-1 $\beta$, and IL-6 was determined at 1 and $24 \mathrm{~h}$ after cisplatin exposure (Fig. 9A-C). Only the MEK1/ERK inhibitors PD98059 and U0126 significantly blocked both the early-phase $(1 \mathrm{~h})$ and late-phase $(24 \mathrm{~h})$ secretions of all three proinflammatory cytokines. Both SB203580 and SP600125 had no affect on TNF- $\alpha$ secretion whereas they caused a slight decrease in the secretion of IL- $1 \beta$ and IL-6. In addition, we confirmed that pharmacological inhibition of MEK1/ERK markedly inhibited the expression levels of TNF- $\alpha$, IL-1 $1 \beta$, and IL-6 mRNA in cisplatin-treated cells (Fig. 9D).

Intraperitoneal injection of cisplatin increased the secretion and expression of proinflammatory cytokines in rats

Next, we examined whether cisplatin increases proinflammatory cytokines in vivo. We then investigated the effect of the therapeutic neutralization of TNF- $\alpha$ by using etanercept, a TNF- $\alpha$ inhibitor, which has been used successfully to neutralize mouse TNF- $\alpha$ in vivo (Satoh et al. 2002). Rats were given intraperitoneal injections of cisplatin for four consecutive days ( $4 \mathrm{mg} / \mathrm{kg}$ body weight per injection), and then the serum levels of three proinflammatory cytokines were measured (Table 1). Serum levels of TNF- $\alpha$, IL-1 $\beta$, and IL-6 were significantly increased in cisplatininjected rats compared to PBS control rats (three- to sevenfold). Interestingly, neutralization of TNF- $\alpha$ by intraperitoneal injection of etanercept significantly decreased the serum levels of IL-1 $\beta$ and IL- 6 in addition to TNF- $\alpha$.

We further examined proinflammatory cytokine mRNA levels in whole cochleae using RT-PCR from the total RNA of whole left cochleae from three experimental groups. Consistent with the levels of secreted protein, the mRNA levels of TNF- $\alpha$, IL- $1 \beta$, and IL-6 were markedly increased after cisplatininjection compared to PBS control rats (Fig. 10). In addition, the simultaneous injection of etanercept and cisplatin not only completely blocked the expression of TNF- $\alpha$ mRNA, but also markedly decreased the expression of other cytokines, including IL-1 $\beta$ and IL-6. These results strongly suggest that TNF- $\alpha$ plays a central role in the expression of other proinflammatory cytokines in rats after cisplatin injection.

To investigate the localization and expression profiles of proinflammatory cytokines in the cochleae after cisplatin injection, immunohistochemistry was performed on rat cochleae after injection with cisplatin only or with cisplatin plus etanercept (Fig. 11). TNF- $\alpha$ staining was observed throughout the stria vascularis (Fig. 11B), spiral ligament (Fig. 11D), spiral limbus (Fig. 11F), modiolar spiral veins and lacunae (data not shown), and hair cell layers in the organ of Corti (Fig. 11E). IL$1 \beta$ was mainly expressed in the spiral ligament (Fig. 12B) and spiral modiolar veins and lacunae (Fig. 12C). Interestingly, TNF- $\alpha$ and IL-1 $\beta$ were colocalized within the spiral ligament (Figs. 11D and 12B). On the other hand, IL-6 was detected only in the spiral modiolar veins and lacunae (Fig. 12A). In both PBS control rats and etanercept/cisplatin-coinjected rats, the staining of all three proinflammatory cytokines was barely detectable (Fig. 11A,C).

Activation of the transcription factor NF- $\mathrm{KB}$ is one of the most important mechanisms regulating the expression of proinflammatory cytokines (Baldwin 1996; Barnes and Karin 1997). Therefore, we next examined the expression profile of NF- $\mathrm{KB}$ in three experimental groups by immunohistochemistry. NF$\mathrm{\kappa B}$ p65 staining was increased in the spiral ligament, stria vascularis, spiral limbus, and the three OHC layers of the organ of Corti in cisplatin-injected rats compared with both PBS control and etanercept/ 
A

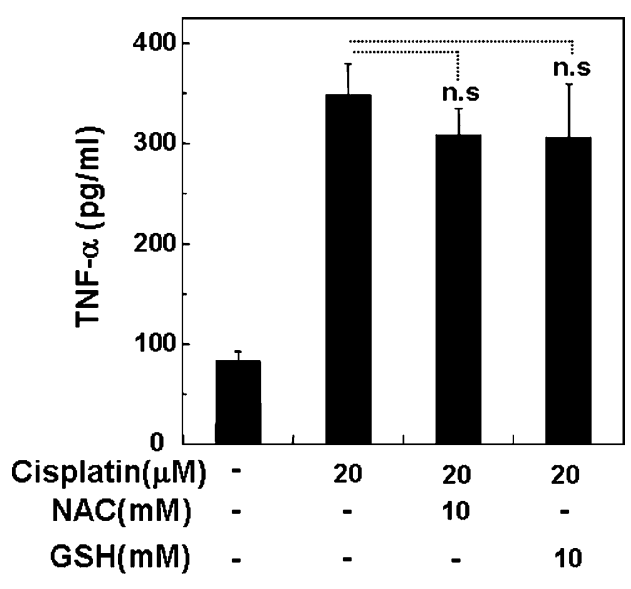

B

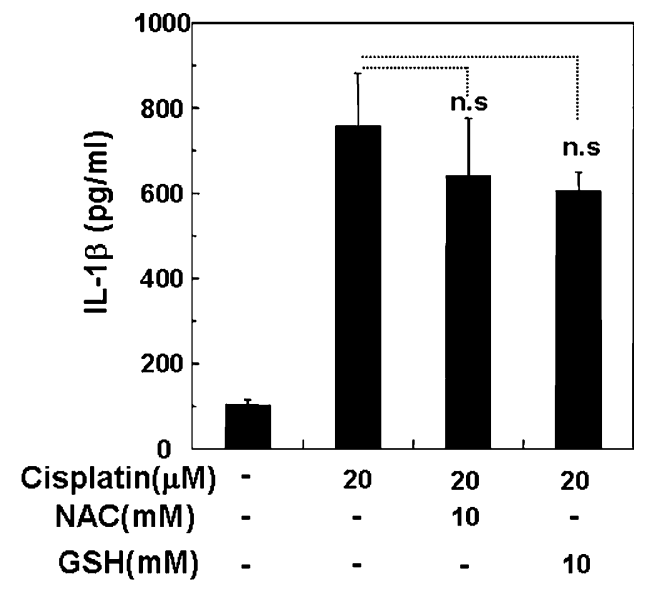

C

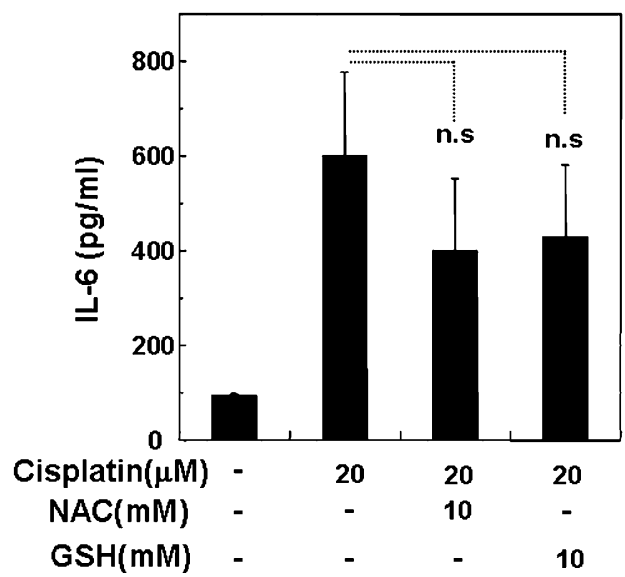

FIG. 6. Effect of antioxidants on cisplatin-induced secretion of proinflammatory cytokines in HEI-OC1 auditory cells. Cells were treated with $20 \mu \mathrm{M}$ cisplatin in the presence of $10 \mathrm{mM}$ concentrations of NAC and GSH for $24 \mathrm{~h}$. Proinflammatory cytokine secretion in culture supernatants was then determined by ELISA. The data represent the mean \pm SD of six culture supernatants. n.s $=$ Not significant. A Release of TNF- $\alpha$, B release of IL-1 $\beta$, and $\mathbf{C}$ release of IL- 6 .

cisplatin-coinjected rats (Fig. 12D-F). We also examined the cochleae for apoptotic cells as determined by TUNEL staining. In cochleae from PBS control or etanercept/cisplatin-coinjected rats, no TUNEL-positive cells were observed (Fig. 12G,I). However, histological sections from cisplatin-only treated rats exhibited TUNEL-positive cells in the stria vascularis, spiral ligament, spiral limbus, and the organ of Corti (Fig. 12H).

\section{DISCUSSION}

Many previous studies suggest that cochlear and vestibular functions, including hearing and balance, are influenced by immune responses in the inner ear (Ma et al. 2000; Rahman et al. 2001). Although immune function in the inner ear is very important in the protection from infectious diseases such as labyrinthitis, immune-related inflammatory responses also cause damage to the delicate tissues of the inner ear compartments and can often lead to cochlear degeneration and permanent hearing loss (Ryan et al. 2002; Satoh et al. 2003; Stone and Francis 2000). However, the exact molecular mechanisms and roles of inflammatory mediators in hearing impairment still remain to be elucidated.

Cisplatin is one of the most widely used chemotherapeutic agents in treatment of human tumors. However, the risk of complications, including ototoxicity and nephrotoxicity, commonly hampers the use of higher doses to maximize its antineoplastic effects (Humes 1999). Ototoxicity after cisplatin therapy is very common and occurs in the OHCs of the organ of Corti (Feghali et al. 2001; Huang et al. 2000; 

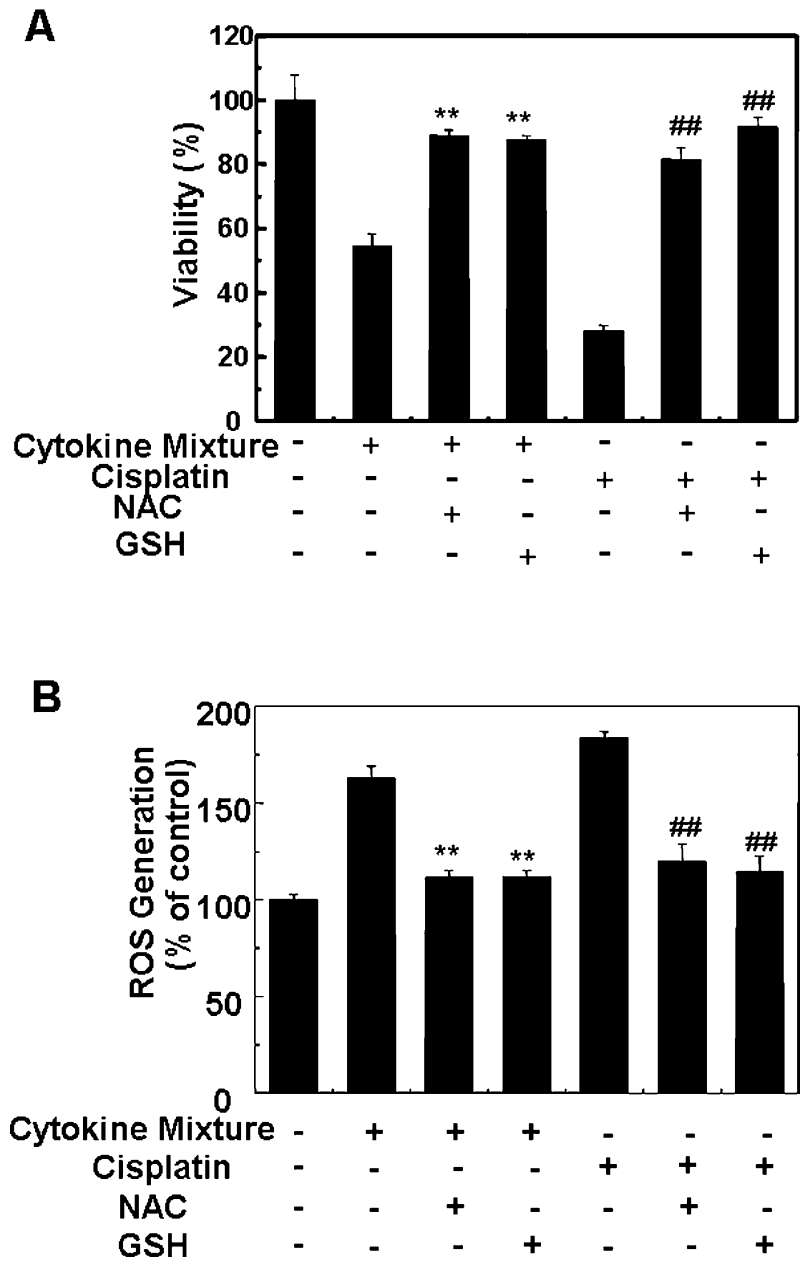

FIG. 7. Effect of proinflammatory cytokines on ROS generation from HEI-OC1 auditory cells. A In the presence of $10 \mathrm{mM}$ NAC or $10 \mathrm{mM} \mathrm{GSH}$, cells were treated with $20 \mu \mathrm{M}$ cisplatin or various cytokine mixtures containing $20 \mathrm{ng} / \mathrm{ml}$ concentrations of TNF- $\alpha$, IL-1 $\beta$, and IL-6, for 36 or 48 h, respectively. Cell viability was measured by MTT assay. B Cells were treated with cisplatin or the cytokine mixture in the presence of NAC and GSH for $24 \mathrm{~h}$. The level of intracellular ROS was monitored using a peroxide-sensitive fluorescent probe, DCFH-DA. ** or \#\# $p<0.01$ by one-way ANOVA compared with cytokine mixture $\left({ }^{* *}\right)$ or cisplatin-treated (\#\#) cells $(n=3)$.

Kopke et al. 1997; Watanabe et al. 2002). In fact, cisplatin induces apoptosis of OHCs in the organ of Corti explants (Kopke et al. 1997) and in vivo (Alam et al. 2000; Watanabe et al. 2002). It is also known that the cytotoxic effects of cisplatin occur via at least two major mechanisms, including the formation of DNA adducts (Huang et al. 2000; Kartalou and Essigmann 2001; Kharbanda et al. 2000) and damage because of the production of ROS (Evans and Halliwell 1999; Feghali et al. 2001; Kopke et al. 1997). These processes ultimately cause cell death by apoptosis or necrosis (Davis et al. 2001; Jordan and Carmo-Fonseca 2000). However, the roles of inflammatory cytokines in the pathogenesis of cis- platin ototoxicity have not been elucidated. In this study, we clearly demonstrate that the secretion and expression of proinflammatory cytokines TNF- $\alpha$, IL$1 \beta$, and IL-6 were increased in HEI-OC1 cells after the addition of cisplatin in vitro, and in the rat cochleae after the peritoneal injection of cisplatin. In addition, our data show that proinflammatory cytokines are directly involved in the death of HEI-OC1 cells after cisplatin exposure. For the first time, we demonstrate that the early immediate secretion of proinflammatory cytokines occurs in auditory cells after cisplatin treatment independent of changes in mRNA expression. These results suggest that HEIOC1 auditory cells may secrete proinflammatory cytokines from preexisting stores after cisplatin

A

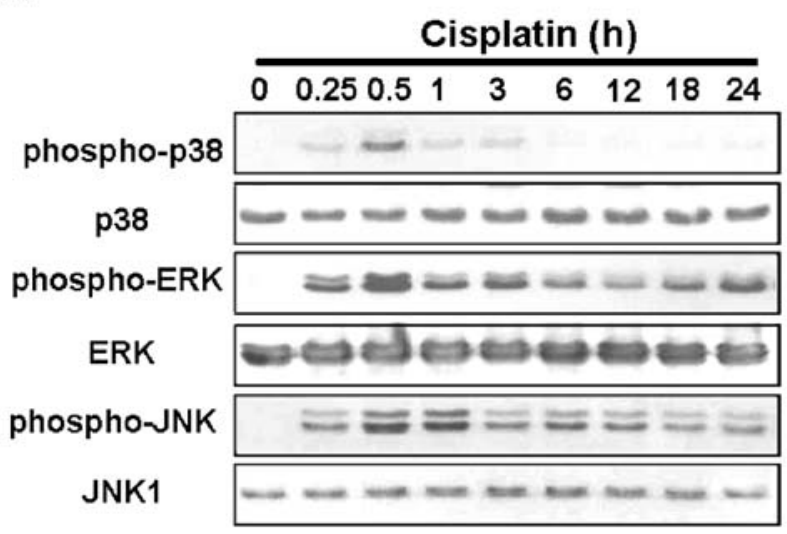

B

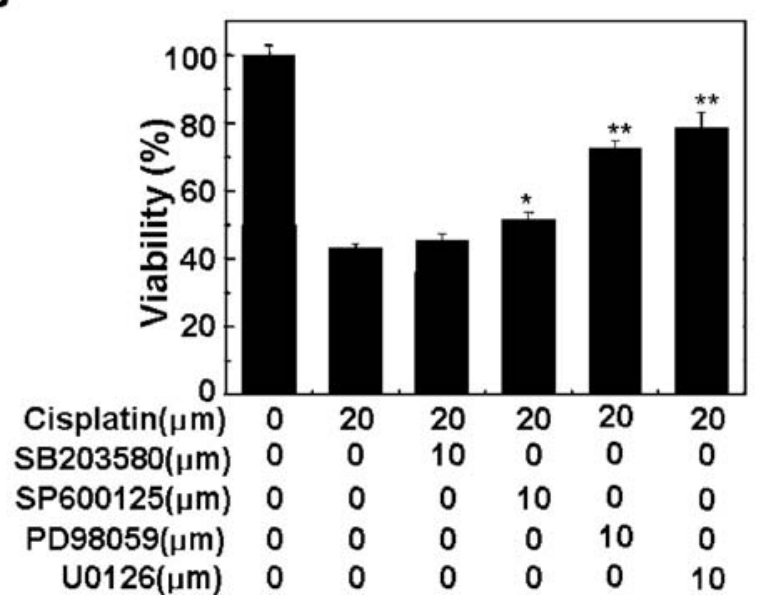

FIG. 8. Phosphorylation of MAPKs in cisplatin-treated HEI-OC1 auditory cells. A Cells were treated with $20 \mu \mathrm{M}$ cisplatin for the indicated time periods and subjected to Western blotting with antiphospho-MAPK and anti-MAPK antibodies. B Cells were pretreated with pharmacological inhibitors of MAPKs for $30 \mathrm{~min}$, and then further treated with cisplatin for $36 \mathrm{~h}$. Cell viability was measured by MTT assay. ${ }^{*} p<0.05$ and ${ }^{* *} p<0.01$ by one-way ANOVA compared with cisplatin-only treated cells $(n=3)$. 
A

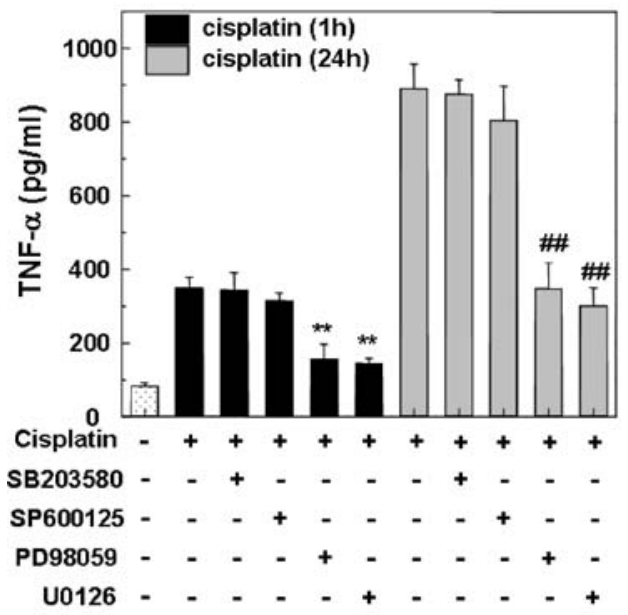

C

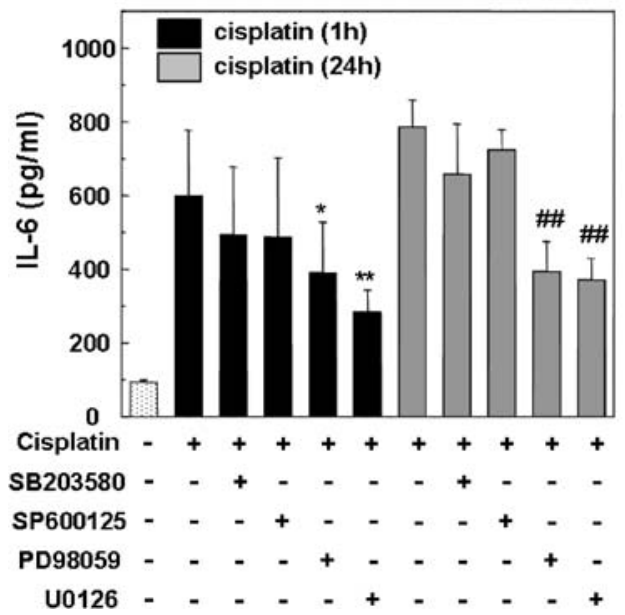

B

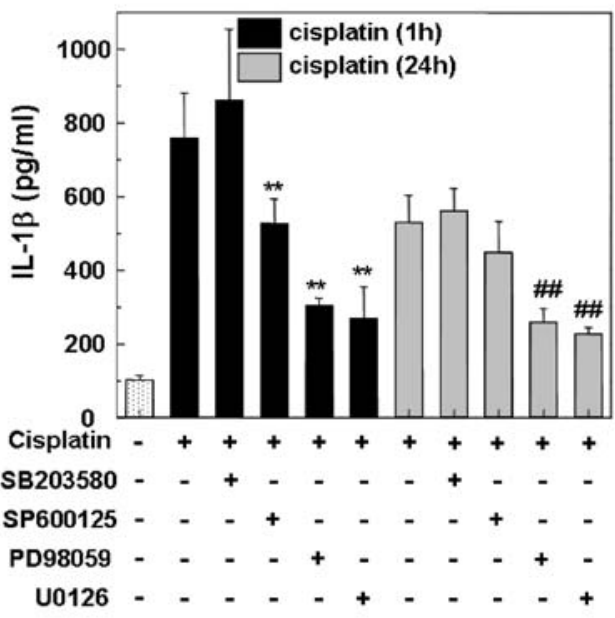

D

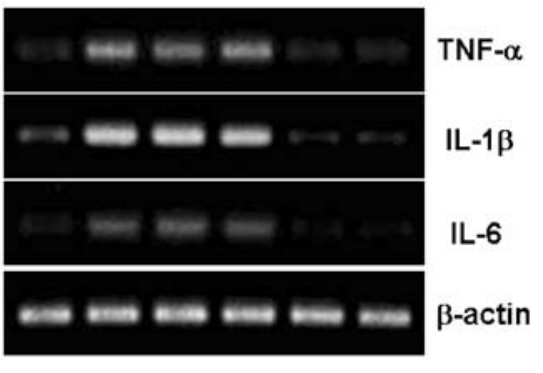

$\begin{array}{rlllll}\text { Cisplatin - } & + & + & + & + & + \\ \text { SB203580 - } & - & + & - & - & - \\ \text { SP600125 - } & - & - & + & - & - \\ \text { PD98059 - } & - & - & - & + & - \\ \text { U0126 - } & - & - & - & - & +\end{array}$

FIG. 9. Effects of pharmacological inhibition of MAPKs on cisplatin-induced secretion and mRNA expression of proinflammatory cytokines in HEI-OC1 auditory cells. Cells were treated with $20 \mu \mathrm{M}$ cisplatin in the presence of $10 \mu \mathrm{M}$ MAPK inhibitors as indicated below each plot. Proinflammatory cytokine secretion in culture supernatants was then determined at 1 and $24 \mathrm{~h}$ after cisplatin exposure by ELISA. A Release of TNF- $\alpha$, B release of IL-1 $\beta$, C release of IL- 6 . The data represent the mean \pm SD of six culture supernatants. * and \# $p<0.05$ and $* *$ and \#\# $p<0.01$ compared with $1 \mathrm{~h}$ cisplatin exposure $\left(*\right.$ and ${ }^{* *}$ ) or $24 \mathrm{~h}$ cisplatin exposure (\# and \#\#). D Total RNA isolated from cells treated with cisplatin and MAPKs inhibitors for $24 \mathrm{~h}$ by TRIzol and cDNA was synthesized by reverse transcriptase. TNF- $\alpha$, IL-1 $\beta$, IL- 6 , and $\beta$-actin cDNA sequences were amplified using specific primer sets.

exposure. It has been reported that both TNF- $\alpha$ and IL-8 are stored in mast cells and are rapidly secreted after various stimuli, initiating late phase allergic reactions and other inflammatory responses (Gibbs et al. 2001). Neutrophils are also known to contain stores of TNF- $\alpha$, IL-12, IL-6, and MIP-2, which play a critical role in inflammation and antimicrobial activity (Bennouna et al. 2005). Our results provide the first direct evidence that TNF- $\alpha$, IL- $1 \beta$ and IL- 6 are also secreted from preexisting stores in addition to their de novo synthesis in cisplatin-treated auditory cells.

$\mathrm{NF}-\mathrm{kB}$ activation is pivotal in the expression of proinflammatory cytokines and other mediators in- volved in acute inflammatory responses and other conditions associated with increased ROS generation (Abraham 2003). TNF- $\alpha$ and IL-1 $\beta$ can activate NF-kB through signal transduction involving the TNF-receptorassociated factor family of adaptor proteins (Dempsey et al. 2003). TNF- $\alpha$ receptors phosphorylate IкB kinase, which in turn leads to IкB degradation in proteosomes and the intranuclear translocation of NF$\kappa \mathrm{B}$ subunits. NF- $\mathrm{\kappa B}$ activation regulates a plethora of genes including proinflammatory cytokines, such as TNF- $\alpha$, IL-1 $\beta$, and IL-6 (Baldwin 1996; Barnes and Karin

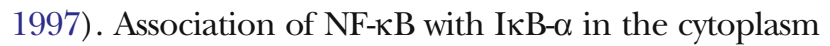
is well known to block the nuclear translocation of NF$\kappa \mathrm{B}$, whereas exposure of cells to proinflammatory 
TABLE 1

Serum cytokine secretion profiles of cisplatin-treated Sprague-Dawley rats

\begin{tabular}{|c|c|c|c|}
\hline \multirow[b]{2}{*}{ Exp. Group } & \multicolumn{3}{|c|}{ Cytokines $(\mathrm{pg} / \mathrm{ml})$} \\
\hline & $T N F-\alpha$ & $I L-1 \beta$ & $I L-6$ \\
\hline Control & $39.1 \pm 7.2$ & $28.7 \pm 4.1$ & $18.5 \pm 3.2$ \\
\hline Cisplatin & $250.5 \pm 57.2$ & $74.0 \pm 17.9$ & $59.7 \pm 1.10$ \\
\hline Etanercept + cisplatin & $50.3 \pm 14.1$ & $44.8 \pm 16.6$ & $28.8 \pm 11.7$ \\
\hline \multicolumn{4}{|l|}{ ANOVA analysis $(n=12)$} \\
\hline Group 1 vs 2 & $p<0.0001$ & $p<0.0001$ & $p<0.0001$ \\
\hline Group 2 vs 3 & $p<0.0001$ & $p<0.0001$ & $p<0.0001$ \\
\hline
\end{tabular}

The animals were randomly divided into three groups of four rats each (group 1 control, group 2 cisplatin-treated, group 3 cisplatin plus etanercept-treated). Group 1 received intraperitoneal injections of PBS for four consecutive days. Group 2 received intraperitoneal injections of cisplatin only (4 mg/kg, body weight) for four consecutive days. Group 3 received etanercept (intraperitoneal injection, $400 \mu \mathrm{g} / \mathrm{kg}$, body weight) $12 \mathrm{~h}$ before and simultaneous with cisplatin injection ( $4 \mathrm{mg} /$ $\mathrm{kg}$, i.p.) for four consecutive days. The animals in all groups were killed under anesthesia on the following day after the final cisplatin injection. Before killing, blood was collected into commercial tubes containing EDTA.

cytokines such as TNF- $\alpha$, IL-1 $\beta$, and IL-6 induces NF- $\kappa$ B activation through $\mathrm{I} \kappa \mathrm{B}$ degradation and the subsequent nuclear translocation of NF- $\mathrm{B}$ (Suzuki et al. 2000; Wang et al. 2003).

In this study, we also demonstrate that cisplatin induces the nuclear translocation of NF- $\mathrm{B}$ through the degradation of cytoplasmic $\mathrm{I} \kappa \mathrm{B}$ and thereby the increase of transcriptional activity of $\mathrm{NF}-\kappa \mathrm{B}$ in vitro. In addition, cisplatin causes the increased $N F-\kappa B$ expression in the spiral ligament, stria vascularis, spiral limbus, and the three OHC layers of the organ of Corti in vivo. We speculate that the early immediate secretion of proinflammatory cytokines in auditory cells by cisplatin may be directly involved in NF- $\mathrm{BB}$ activation. This was further confirmed by our demonstration that the functional blocking of the early secretion of TNF- $\alpha$ with neutralizing antibody prevented the nuclear translocation of $\mathrm{NF}-\kappa \mathrm{B}$ in cisplatintreated HEI-OC1 cells. Exogenous treatment with proinflammatory cytokines could also induce the

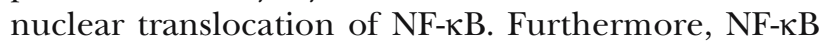
p65 protein expression largely overlapped with $\mathrm{TNF}-\alpha$, IL-1 $\beta$, and IL- 6 staining in the cochleae of cisplatininjected rats.

The elucidation of a cascade of proinflammatory cytokines, NF- $\mathrm{KB}$ activation, and ROS generation is very important for the understanding of the pathogenesis of cisplatin ototoxicity. TNF- $\alpha$ and IL-1 $\beta$ induce the generation of ROS produced mainly by $\mathrm{NADPH}$ oxidase in the membranes of various cell types, including fibroblasts, kidney mesangial cells, endothelial cells, and smooth muscle cells (Tolando et al. 2000). However, a number of groups have also demonstrated that TNF- $\alpha$ induces apoptotic cell death via ROS generation (Garg and Aggarwal 2002). In our study, we showed that antioxidants such as NAC and GSH significantly increased the viability of cisplatin- and proinflammatory cytokinetreated cells. However, neither antioxidant affected the early immediate secretion of proinflammatory cytokines in cisplatin-treated HEI-OC1 cells. These results suggest that the cisplatin-mediated secretion of proinflammatory cytokines is upstream signal of ROS production. This was further confirmed by the fact that exogenous treatment with proinflammatory cytokines significantly increased the generation of intracellular ROS. Thus, considering the time-dependent kinetics of NF- $\mathrm{B}$ nuclear translocation (maximum at 1 or $2 \mathrm{~h}$ after cisplatin) and ROS generation (maximum at $24 \mathrm{~h}$ or $30 \mathrm{~h}$ ) (So et al. 2005), we speculate that the mechanism of cisplatin cytotoxicity comes from two different arms: (1) the immediate early activation of $\mathrm{NF}-\kappa \mathrm{B}$ because of the release of preexisting stores of proinflammatory cytokines, and (2) the de novo synthesis of proinflammatory cyto-

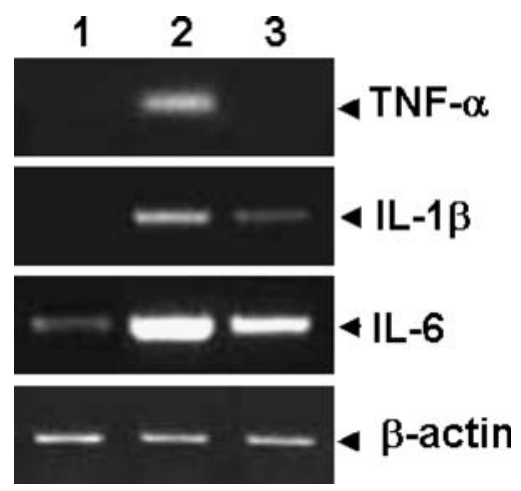

FIG. 10. In vivo effect of cisplatin on mRNA levels of proinflammatory cytokine genes in the cochleae. Three groups of SD rats were injected intraperitoneally with PBS, cisplatin, or cisplatin plus etanercept. Total RNA was then isolated from whole cochleae and cDNA was synthesized by reverse transcriptase. TNF- $\alpha$, IL-1 $\beta$, IL- 6 , and $\beta$-actin cDNA sequences were amplified using specific rat primer sets. The assay was repeated two times independently. The representative data are shown. $1=$ Whole cochleae from control rat, 2 = whole cochleae from cisplatin-treated rat, and $3=$ whole cochleae from cisplatin/etanercept-treated rat. 
kines and subsequent ROS production at later time points.

MAPKs regulate many cellular events, including differentiation, proliferation, and apoptosis (Lewis et al. 1998). It has also been reported that p38 and ERK pathways play an important role in IL-1 $\beta$ and TNF- $\alpha$ production, respectively (Hsu and Wen 2002; Shi et al. 2002). Herein, our data demonstrate that all three types of MAPKs are activated in cisplatin-treated cells. Pharmacologic inhibition of ERK activity is much more effective in the suppression of proinflammatory cytokine secretion and the prevention of cell death in cisplatintreated HEI-OC1 auditory cells compared to the inhibition of p38 and JNK. The biochemical/molecular mechanisms by which cisplatin induces early proinflammatory cytokine release are still not fully understood. However, considering that the early immediate secretion of proinflammatory cytokines was significantly blocked by the pharmacologic inhibition of ERK activity, we suggest that ERK activation is critical for the release of preexisting stores of inflammatory cytokines, as well as the delayed production of proinflammatory cytokines by de novo synthesis. In addition, intraperitoneal injection with cisplatin clearly resulted in an increase of proinflammatory cytokines in both serum and the cochleae. Interestingly, etanercept, a fusion protein derived from a soluble TNF- $\alpha$ receptor and the $\mathrm{F}_{\mathrm{C}}$ chain of human $\mathrm{IgG}$, significantly reduced the serum levels of proinflammatory cytokines. It also blunted the cisplatin-induced expression of mRNA and protein of proinflammatory cytokines in the cochleae. Immunohistochemical investigation of the location of proinflammatory cytokine production in the cochleae after cisplatin showed that these cytokines are predominantly expressed in the spiral ligament, spiral limbus, spiral modiolar veins, and lacunae. In addition, TNF- $\alpha$ expression was observed in the OHC layers of the organ of Corti. This implies that TNF- $\alpha$ may directly mediate damage to hair cell layers, causing hearing impairment.

It is very important to elucidate the cellular source of inflammatory cytokines in cisplatin ototoxicity. Many studies suggest that infiltration of inflammatory cells, including lymphocytes, polymorphonuclear leukocytes, monocytes, and macrophages, into the cochleae is an important cellular source of inflammatory cytokines. Inflammatory cells are assumed to migrate to the cochleae from the endolymphatic sac (Satoh et al. 2003; Tomiyama and Harris 1986), or from the systemic circulation through the spiral modiolar vein (Harris et al. 1990). These inflammatory cells play a pivotal role in defending against invading pathogens and foreign proteins, but inflammatory reactions generated by such cells may cause cochlear damage and lead to hearing loss. However,

\section{A Control}

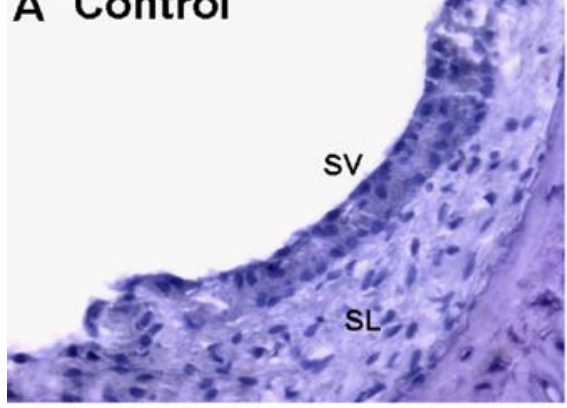

\section{Cisplatin}

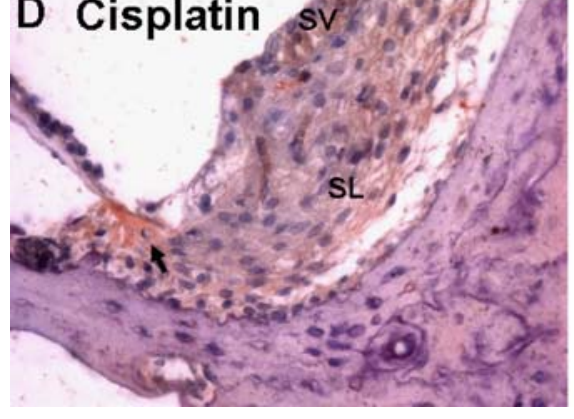

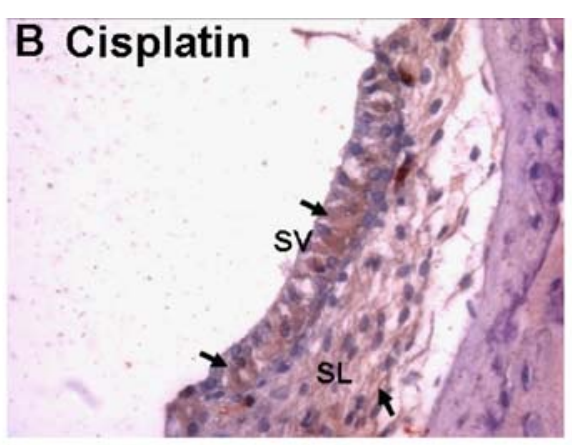

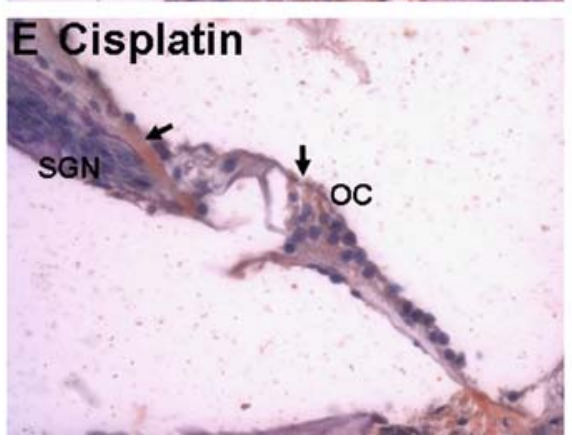

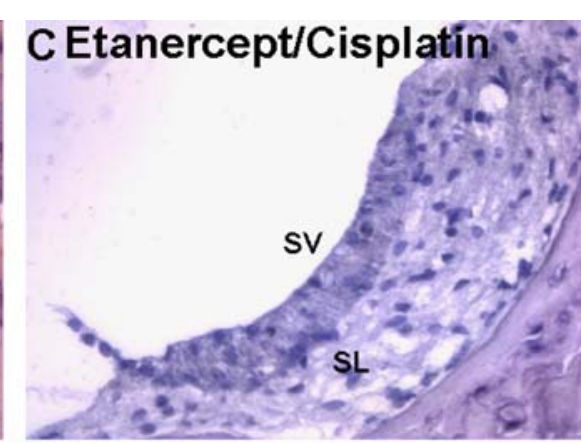

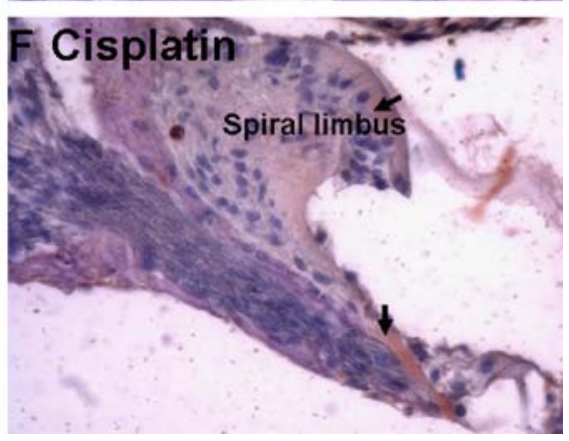

FIG. 11. In vivo effect of cisplatin on TNF- $\alpha$ expression in the cochleae. Cochleae from rats injected with PBS, cisplatin, or cisplatin plus etanercept were removed and embedded in paraffin, then $5 \mu \mathrm{m}$ sections were prepared and stained with anti-TNF- $\alpha$ antibody. The stria vascularis and spiral ligament of control rats (A), cisplatin-treated rats (B), and cisplatin-treated rats in the presence of etanercept $(\mathbf{C})$. D Junctional regions of the organ of Corti and spiral ligament in cisplatin-treated rats. E The organ of Corti of cisplatin-treated rats. F Spiral limbus of cisplatin-treated rats. This figure is representative of three individual animals from each group. SL = Spiral ligament, SV = stria vascularis, SGN = spiral ganglion neuron, $\mathrm{OC}=$ organ of Corti. 

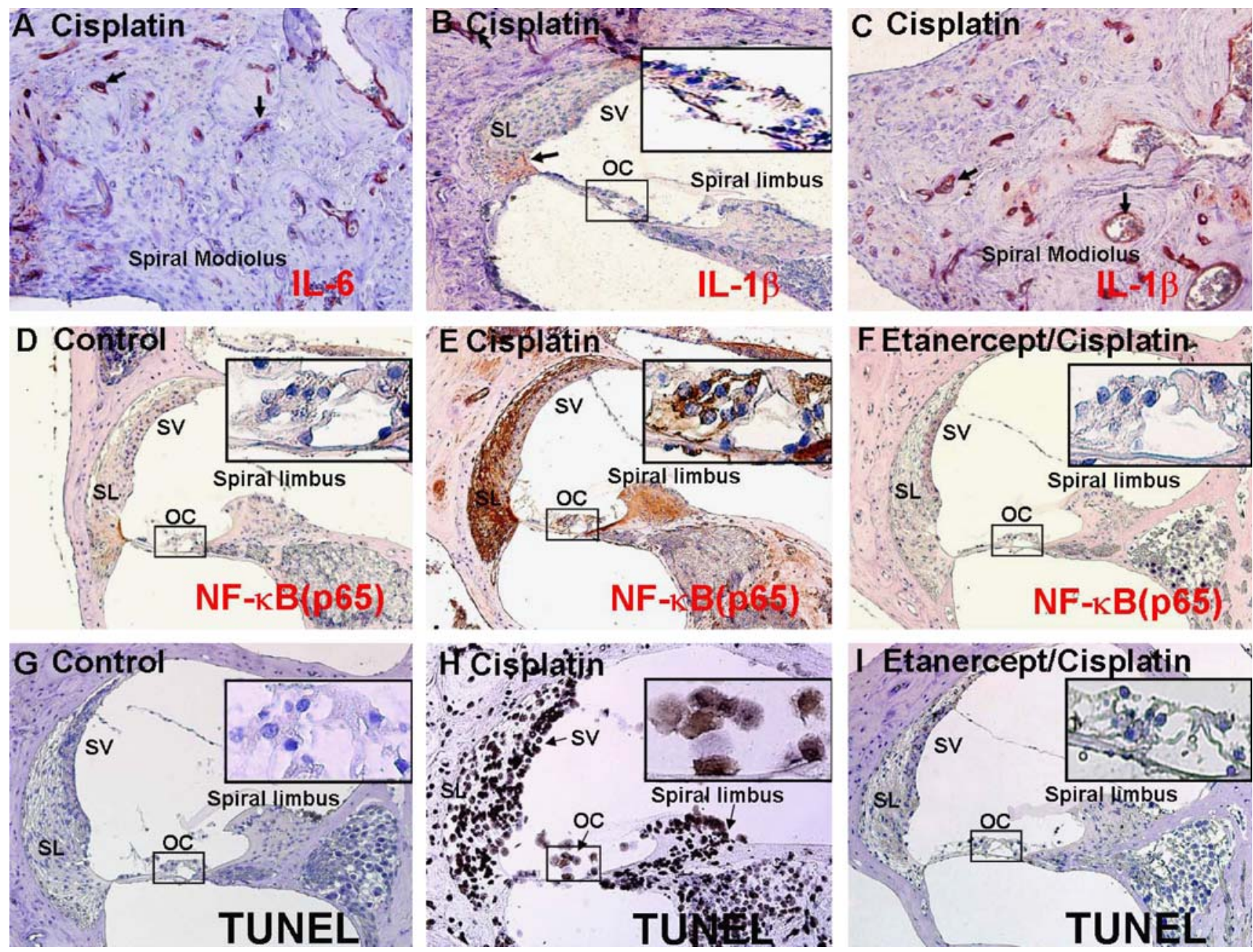

FIG. 12. In vivo effect of cisplatin on the protein expression of proinflammatory cytokines and TUNEL staining in the cochleae. Fivemicrometer cochlear sections from each experimental group were stained with anti-IL-6 (A), IL-1 $\beta$ (B, C), NF- $\mathrm{kB}$ (D-F), and TUNEL (G-I). A IL-6 in spiral modiolar vein. B IL-1 $\beta$ in stria vascularis, spiral ligament, and the organ of Corti. C IL-1 $\beta$ in the spiral modiolar vein. $\mathbf{D}$ NF- $\kappa B$ in whole

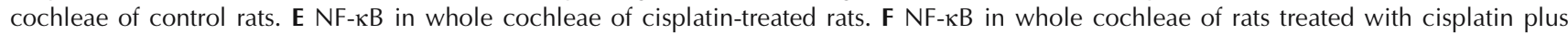
etanercept. G Whole cochleae of control rats. $\mathbf{H}$ Whole cochleae of cisplatin-treated rats. I Whole cochleae of rats treated with cisplatin plus etanercept. This figure is representative of three individual animals from each group. $\mathrm{SL}=$ Spiral ligament, $\mathrm{SV}=$ stria vascularis, $\mathrm{OC}=$ organ of Corti.

interestingly, we could not observe the infiltrated leukocytes in the histological sections from cisplatininjected rats stained with hematoxylin and eosin (data not shown). This result suggests a possibility that there are other cellular sources of inflammatory cytokines in cisplatin ototoxicity in addition to endolymphatic sac and spiral modiolar vein. Furthermore, it has been reported that spiral ligament fibrocytes can secrete chemokines and other inflammatory mediators after stimulation with TNF- $\alpha$ and IL-1 $\beta$ (Yoshida et al. 1999), which might induce the infiltration of inflammatory cells and cause cochlear dysfunction because of cochlear inflammation. In this study, we demonstrate that TNF- $\alpha$ is ubiquitously expressed throughout the spiral ligament and stria vascularis after cisplatin injection. Immunoreactivity to IL-1 $\beta$ was also observed in the same region of the spiral ligament. These data suggest that spiral ligament fibrocytes may induce inflammatory cytokine production in cisplatin ototoxicity, and may also be cellular targets for inflammatory cytokines. Our study also suggests the possibility that auditory cells in the organ of Corti may be an important additional source of inflammatory cytokines.

It has been recently shown that the integrity of the spiral ligament is critical for the normal functioning of the stria vascularis and, consequently, of the organ of Corti. Many studies indicate that the potassium ions used in the transduction of auditory signals by the sensory cells of the organ of Corti are recycled (Kikuchi et al. 1995), and that potassium uptake from the perilymphatic space is mediated primarily 
by Type II and IV fibrocytes in the ligament (Hibino et al. 2004; Kikuchi et al. 1995), which abundantly expresses $\mathrm{Na}^{+}, \mathrm{K}^{+}$-ATPase and $\mathrm{Na}^{+}, \mathrm{K}^{+}, 2 \mathrm{Cl}^{-}$cotransporter (Hibino et al. 2004). Through these types of fibrocytes, potassium enters the stria vascularis via connective tissue gap junctions and potassium channels (Hibino et al. 2004; Kikuchi et al. 1995). The strial marginal cells then return potassium to the scala media, where it is once again available to sensory hair cells. Interestingly, it has been reported that the expression and function of gap junction proteins such as connexins in other systems (including lung and kidney) were controlled by inflammatory cytokines (Duffy et al. 2000; Hu and Cotgreave 1997; Temme et al. 1998). Moreover, the function of ion channels is known to be altered by inflammatory cytokines (Carlson et al. 1999; Soliven et al. 1991). Therefore, it seems that both alteration of ion homeostasis and disruption of gap junctions within spiral ligaments by proinflammatory cytokines may be closely related to the destruction of cochlear structure and hearing loss caused by cisplatin.

Taken together, our data demonstrate for the first time that proinflammatory cytokines may play a critical role in cisplatin-induced cochlear injury. TNF- $\alpha$ plays a key role in this process because the inhibition of TNF- $\alpha$ action significantly attenuates the expression of other proinflammatory cytokines after cisplatin injection. These findings are particular interest because of inflammation being another mechanism in the pathogenesis of cisplatin ototoxicity. In addition, elucidation of the intracellular mechanisms that participate in cisplatin damage to the inner ear may provide new opportunities for pharmacotherapy with regard to cisplatin and immune-mediated disorders of hearing and balance.

\section{ACKNOWLEDGEMENTS}

This work was supported by the Ministry of Science and Technology/Korea Science and Engineering Foundation through the Vestibulocochlear Research Center at Wonkwang University in 2006 (R13-2002-055-00000-0). Hongseob So and HyungJin Kim equally contributed to this work.

\section{REFERENCES}

Авraham E. Nuclear factor-kappaB and its role in sepsis-associated organ failure. J. Infect. Dis. 187 (Suppl 2):S364-S369, 2003.

Alam SA, Ikeda K, Oshima T, Suzuki M, Kawase T, Kikuchi T, TAKASAKA T. Cisplatin-induced apoptotic cell death in Mongolian gerbil cochlea. Hear Res. 141:28-38, 2000.

Arany I, Megyesi JK, Kaneto H, Price PM, Safirstein RL. Cisplatininduced cell death is EGFR/src/ERK signaling dependent in mouse proximal tubule cells. Am. J. Physiol. Renal. Physiol. 287:F543-F549, 2004.
Baldwin AS, JR. The NF-kappa B and I kappa B proteins: new discoveries and insights. Annu. Rev. Immunol. 14:649-683, 1996.

BARNeS PJ, KARIN M. Nuclear factor-kappaB: a pivotal transcription factor in chronic inflammatory diseases. N. Engl. J. Med. 336:1066-1071, 1997.

Bennouna S, Denkers EY. Microbial antigen triggers rapid mobilization of TNF-alpha to the surface of mouse neutrophils transforming them into inducers of high-level dendritic cell TNF-alpha production. J. Immunol. 174:4845-4851, 2005.

Carlson NG, Wieggel WA, Chen J, Bacchi A, Rogers SW, Gahring LC. Inflammatory cytokines IL-1 alpha, IL-1 beta, IL-6, and TNF-alpha impart neuroprotection to an excitotoxin through distinct pathways. J. Immunol. 163:3963-3968, 1999.

Davis CA, Nick HS, Agarwal A. Manganese superoxide dismutase attenuates cisplatin-induced renal injury: importance of superoxide. J. Am. Soc. Nephrol. 12:2683-2690, 2001.

Dempsey PW, Doyle SE, He JQ, Cheng G. The signaling adaptors and pathways activated by TNF superfamily. Cytokine Growth Factor Rev. 14:193-209, 2003.

Duffy HS, John GR, Lee SC, Brosnan CF, Spray DC. Reciprocal regulation of the junctional proteins claudin-1 and connexin 43 by interleukin-1beta in primary human fetal astrocytes. J. Neurosci. 20:RC114, 2000.

Evans P, Halliwell B. Free radicals and hearing. Cause, consequence, and criteria. Ann. N. Y. Acad. Sci. 884:19-40, 1999.

Feghali JG, Liu W, Van De Water TR. L-n-acetyl-cysteine protection against cisplatin-induced auditory neuronal and hair cell toxicity. Laryngoscope 111:1147-1155, 2001.

Fram RJ. Cisplatin and platinum analogues: recent advances. Curr. Opin. Oncol. 4:1073-1079, 1992.

Garg AK, Aggarwal BB. Reactive oxygen intermediates in TNF signaling. Mol. Immunol. 39:509-517, 2002.

Ghosh S, MaY MJ, Kopp EB. NF-kappa B and Rel proteins: evolutionarily conserved mediators of immune responses. Annu. Rev. Immunol. 16:225-260, 1998.

Gibbs BF, Wierecky J, Welker P, Henz BM, Wolff HH, Grabbe J. Human skin mast cells rapidly release preformed and newly generated TNF-alpha and IL-8 following stimulation with antiIgE and other secretagogues. Exp. Dermatol. 10:312-320, 2001.

Guha M, O’Connell MA, Pawlinski R, Hollis A, McGovern P, Yan SF, Stern D, Mackman N. Lipopolysaccharide activation of the MEK-ERK1/2 pathway in human monocytic cells mediates tissue factor and tumor necrosis factor alpha expression by inducing Elk-1 phosphorylation and Egr-1 expression. Blood 98:1429-1439, 2001.

HARRIS, JP. Immunology of the inner ear: evidence of local antibody production. Ann. Otol. Rhinol. Laryngol. 93:157$162,1984$.

Harris JP, Fukuda S, Keithley EM. Spiral modiolar vein: its importance in inner ear inflammation. Acta Otolaryngol. 110:357-365, 1990.

Hibino H, Higashi-Shingai K, Fujta A, Inai K, Ishit M, Kurachi Y. Expression of an inwardly rectifying $\mathrm{K}+$ channel, Kir5.1, in specific types of fibrocytes in the cochlear lateral wall suggests its functional importance in the establishment of endocochlear potential. Eur. J. Neurosci. 19:76-84, 2004.

Hsu HY, Wen MH. Lipopolysaccharide-mediated reactive oxygen species and signal transduction in the regulation of interleukin-1 gene expression. J. Biol. Chem. 277:22131-22139, 2002.

Hu J, Cotgreave IA. Differential regulation of gap junctions by proinflammatory mediators in vitro. J. Clin. Invest. 99:23122316, 1997.

Huang T, Cheng AG, Stupak H, Liu W, Kim A, Staecker H, Lefebvre PP, Malgrange B, Kopke R, Moonen G, Van De Water TR. Oxidative stress-induced apoptosis of cochlear sensory cells: otoprotective strategies. Int. J. Dev. Neurosci. 18:259-270, 2000. 
Humes HD. Insights into ototoxicity. Analogies to nephrotoxicity. Ann. N. Y. Acad. Sci. 884:15-18, 1999.

Jordan P, CARMo-Fonseca M. Molecular mechanisms involved in cisplatin cytotoxicity. Cell. Mol. Life Sci. 57:1229-1235, 2000.

Kalinec GM, Webster P, Lim DJ, Kalinec F. A cochlear cell line as an in vitro system for drug ototoxicity screening. Audiol. Neurootol. 8:177-189, 2003.

KANZAKi J, OUchi T. Steroid-responsive bilateral sensorineural hearing loss and immune complexes. Arch. Otorhinolaryngol. 230:5-9, 1981.

Kartalou M, Essigmann JM. Recognition of cisplatin adducts by cellular proteins. Mutat. Res. 478:1-21, 2001.

Kaushal GP, Kaushal V, Hong X, Shah SV. Role and regulation of activation of caspases in cisplatin-induced injury to renal tubular epithelial cells. Kidney Int. 60:1726-1736, 2001.

Kharbanda S, Pandey P, Yamauchi T, Kumar S, Kaneki M, Kumar V, Bharti A, Yuan ZM, Ghanem L, Rana A, Weichselbaum R, Johnson G, KuFE D. Activation of MEK kinase 1 by the c-Abl protein tyrosine kinase in response to DNA damage. Mol. Cell Biol. 20:4979-4989, 2000.

Kikuchi T, Kimura RS, Paul DL, Adams JC. Gap junctions in the rat cochlea: immunohistochemical and ultrastructural analysis. Anat. Embryol. (Berl) 191:101-118, 1995.

Kopke RD, Liu W, Gabaizadeh R, Jacono A, Feghali J, Spray D, Garcia P, Steinman H, Malgrange B, Ruben RJ, Rybak L, Van de Water TR. Use of organotypic cultures of Corti's organ to study the protective effects of antioxidant molecules on cisplatin-induced damage of auditory hair cells. Am. J. Otol. 18:559-571, 1997.

Leibbrandt Me, Wolfgang GH, Metz AL, Ozobia AA, Haskins JR. Critical subcellular targets of cisplatin and related platinum analogs in rat renal proximal tubule cells. Kidney Int. 48:761$770,1995$.

LEWIS TS, SHAPIRo PS, AHN NG. Signal transduction through MAP kinase cascades. Adv. Cancer Res. 74:49-139, 1998.

Ma C, Billings P, Harris JP, Keithley EM. Characterization of an experimentally induced inner ear immune response. Laryngoscope 110:451-456, 2000.

Mansouri A, Ridghay LD, Korapati AL, Zhang Q Tian L, Wang Y, Siddik ZH, Mills GB, Claret FX. Sustained activation of JNK/ p38 MAPK pathways in response to cisplatin leads to Fas ligand induction and cell death in ovarian carcinoma cells. J. Biol. Chem. 278:19245-19256, 2003.

Matsushima H, Yonemura K, Ohishi K, Hishida A. The role of oxygen free radicals in cisplatin-induced acute renal failure in rats. J. Lab. Clin. Med. 131:518-526, 1998.

MCCABE BF. Autoimmune sensorineural hearing loss. 1979. Ann. Otol. Rhinol. Laryngol. 113:526-530, 2004.

Rahman MU, Poe DS, ChOi HK. Autoimmune vestibulo-cochlear disorders. Curr. Opin. Rheumatol. 13:184-189, 2001.

Ramesh G, ReEves WB. TNF-alpha mediates chemokine and cytokine expression and renal injury in cisplatin nephrotoxicity. J. Clin. Invest. 110:835-842, 2002.

Ramesh G, Reeves WB. Salicylate reduces cisplatin nephrotoxicity by inhibition of tumor necrosis factor-alpha. Kidney Int. 65:490499, 2004

RIES F, KLASTERSKY J. Nephrotoxicity induced by cancer chemotherapy with special emphasis on cisplatin toxicity. Am. J. Kidney Dis. 8:368-379, 1986.

Ryan AF, Harris JP, Keithley EM. Immune-mediated hearing loss: basic mechanisms and options for therapy. Acta Otolaryngol. Suppl., 38-43, 2002.
Rybak LP, Whitworth C, Somani S. Application of antioxidants and other agents to prevent cisplatin ototoxicity. Laryngoscope 109:1740-1744, 1999.

Satoh H, Firestein GS, Billings PB, Harris JP, Keithley EM. Tumor necrosis factor-alpha, an initiator, and etanercept, an inhibitor of cochlear inflammation. Laryngoscope 112:1627-1634, 2002.

Satoh H, Firestein GS, Billings PB, Harris JP, Keithley EM. Proinflammatory cytokine expression in the endolymphatic sac during inner ear inflammation. J. Assoc. Res. Otolaryngol. 4:139-147, 2003.

Shen J, Sakaida I, Uchida K, Terai S, Okita K. Leptin enhances TNFalpha production via p38 and JNK MAPK in LPS-stimulated Kupffer cells. Life Sci. 77:1502-1515, 2005.

Shi L, Kishore R, McMullen MR, Nagy LE. Lipopolysaccharide stimulation of ERK1/2 increases TNF-alpha production via Egr-1. Am. J. Physiol. Cell Physiol. 282:C1205-C1211, 2002.

So H, Rho J, Jeong D, Park R, Fisher DE, Ostrowski MC, Choi Y, Kim N. Microphthalmia transcription factor and PU.1 synergistically induce the leukocyte receptor osteoclast-associated receptor gene expression. J. Biol. Chem. 278:24209-24216, 2003.

So HS, Park C, Kim HJ, Lee JH, Park SY, Lee ZW, Kim HM, Kalinec F, Lim DJ, Park R. Protective effect of T-type calcium channel blocker flunarizine on cisplatin-induced death of auditory cells. Hear Res. 204:127-139, 2005.

Soliven B, Szuchet S, NeLson DJ. Tumor necrosis factor inhibits K+ current expression in cultured oligodendrocytes. J. Membr. Biol. 124:127-137, 1991.

Stone JH, Francis HW. Immune-mediated inner ear disease. Curr. Opin. Rheumatol. 12:32-40, 2000.

Sugiyama S, Hayakawa M, Kato T, Hanaki Y, Shimizu K, Ozawa T. Adverse effects of anti-tumor drug, cisplatin, on rat kidney mitochondria: disturbances in glutathione peroxidase activity. Biochem. Biophys. Res. Commun. 159:1121-1127, 1989.

Suzuki M, Tetsuka T, Yoshida S, Watanabe N, Kobayashi M, Matsui N, Окамото T. The role of p38 mitogen-activated protein kinase in IL-6 and IL-8 production from the TNF-alpha- or IL-1beta-stimulated rheumatoid synovial fibroblasts. FEBS Lett. 465:23-37, 2000.

Temme A, Traub O, Willecke K. Downregulation of connexin32 protein and gap-junctional intercellular communication by cytokine-mediated acute-phase response in immortalized mouse hepatocytes. Cell Tissue Res. 294:345-350, 1998.

Tolando R, Jovanovic A, Brigelius-Flohe R, Ursini F, Maiorino M. Reactive oxygen species and proinflammatory cytokine signaling in endothelial cells: effect of selenium supplementation. Free Radic. Biol. Med. 28:979-986, 2000.

TOMIYAMA S, HarRIS JP. The endolymphatic sac: its importance in inner ear immune responses. Laryngoscope 96:685-691, 1986.

Wada T, Penninger JM. Mitogen-activated protein kinases in apoptosis regulation. Oncogene 23:2838-2849, 2004.

Wang L, Walia B, Evans J, Gewirtz AT, Merlin D, Sitaraman SV. IL-6 induces NF-kappa B activation in the intestinal epithelia. J. Immunol. 171:3194-3201, 2003.

Watanabe KC, Jinnouchi K, Hess A, Michel O, Baba S, Yagi T. Carboplatin induces less apoptosis in the cochlea of guinea pigs than cisplatin. Chemotherapy 48:82-87, 2002.

Widmann C, Gibson S, Jarpe MB, Johnson GL. Mitogen-activated protein kinase: conservation of a three-kinase module from yeast to human. Physiol. Rev. 79:143-180, 1999.

Yoshida K, Ichimira I, Suzuki M, Mogi G. Effect of proinflammatory cytokines on cultured spiral ligament fibrocytes. Hear Res. 137:155-159, 1999. 